\title{
BIBLIOGRAFIE VAN DE GESCHIEDENIS VAN GENT 2001-20021
}

\author{
Leen Charles ${ }^{2}$ \& Marie Christine Laleman ${ }^{3}$ \& Valérie Meillander ${ }^{4}$
}

Inventarissen, archiefbeschrijvingen, repertoria, bibliografieën (2053-2066), Archeologische kronieken (2067-2072), Algemeen (2073-2080), Prehistorie, Romeinse en Merovingische tijden(2081), Middeleeuwen (2082-2093), Moderne Tijden (2094-2108), Hedendaagse tijd (2109-2127), Industriële archeologie (2128-2138), Kerkgeschiedenis, kloosters (2139-2143), Gebouwen, monumenten, stadsbeeld (2144-2186), Kunst, cultuur (21872213), Materiële cultuur (2214-2218), Heemkunde, volkskunde, genealogie (2219-2265), Biografieën (2267-2285).

\section{Inventarissen, archiefbeschrijvingen, repertoria, bibliografieën}

2053. BOURGEOIS J., J. SEMEY \& M. MEGANCK, Archeologie in vogelperspectief, in Monumentenzorg en Cultuurpatrimonium. Jaarverslag van de Provincie Oost-Vlaanderen 2000, Gent, 2001, p. 40-61. Luchtfotografische prospectie is een belangrijk instrument voor het wetenschappelijk onderzoek van archeologische sites. De inventaris van de talrijke beeldopnamen en hun betekenis zoals die door de Universiteit Gent werd samengesteld, is eveneens een onmisbaar onderdeel voor een goed beheer van het archeologisch erfgoed. Met verschillende verwijzingen van Gent, Sint-Denijs-Westrem en de onmiddellijke omgeving. Geillustreerd.

2054. CAUCHIES J.M., Ordonnances de Jean Sans Peur 1405-1419, première section, tome III, in Recueil des Ordonnances des Pays-Bas. Première série: 1381-1506 / Verzameling van de verordeningen der Nederlanden. Eerste reeks: 1381-1506, Brussel, 2001, 577 blz. Kritisch apparaat. Chronologisch overzicht met onder andere een aantal ordonnanties die betrekking hebben op Gent.

1 Deze bibliografie werd afgesloten per 31/8/2002. Ten einde een zo groot mogelijke volledigheid van de bijdragen te kunnen verwezenlijken, roepen we graag de auteurs op overdrukjes van hun werk te bezorgen aan het Stadsarchief, Abrahamstraat 13, 9000 Gent. Deze bijdragen worden dan in de bibliotheek van het Stadsarchief opgenomen.

2 Stadsarchivaris, Abrahamstraat 13, 9000 Gent, 09/225.32.53 fax. 09/233.11.58 e-mail stadsarchief@gent.be

3 Adviseur Stadsarcheoloog, Hof van Ryhove, Onderstraat 20, 9000 Gent, 09/266.57.60 fax. 09/223.99.19 e-mail stadsarcheologie@gent.be

4 Historicus, Stadsarchief, Abrahamstraat 13,9000 Gent, 09/225.32.53 fax. 09/223.11.58 e-mail stadsarchief@gent.be 
2055. CHARLES L., M.C. LALEMAN \& V. MEILLANDER, Bibliografie van de geschiedenis van Gent 2000-2001, in Handelingen der Maatschappij voor Geschiedenis en Oudheidkunde te Gent, (2001), nr. LV, p. 467-519.

2056. DE BLEECKER M. en A. VERBEKE, Indices op de Ghendtsche Tydinghen (1972-2000), bijlage bij Ghendtsche Tydinghen, 30, (2001), nr. 6, $156 \mathrm{blz}$.

2057. DE NEEF G., H. DE STAELE \& Y. SEGHERS, Inventaris van het archief van de familie Casier ca. 1842-1977, (Kadoc), Leuven, 2002. Het archief omvat vooral stukken met betrekking tot Désiré Casier (1824-1915), Fernand Casier (1880-1977) en bovenal Joseph Casier (1852-1925). De archiefdocumenten geven informatie van zowel familiale aard als met betrekking tot het bedrijfsleven (textiel), de maatschappelijke positie van de Casier's en hun betekenis voor de ontplooiing van de kunst, in hoofdzaak de neogotiek. Het archief Casier bevat ook een unieke fotocollectie.

2058. DE VUYST W., A la recherche d'une ville disparue. De fotoverzameling van de SCMS, in @ rchieflink, 2 (2002),nr. 3, p. 1-2. Ter gelegenheid van de digitalisering werd ook een inventaris opgezet met de nummering en zoveel mogelijk gegevens over de foto's uit deze verzameling, zo'n 7500 stuks. Tevens werden een aantal gegevens verzameld over de vorming en de ontwikkeling van de collectie. Met verwijzing ook naar de digitale Beeldbank Gent.

2059. DOUXCHAMPS J., Nos anciennes corporations de metiers. Repertoire bibliographique, Wepion, 2002, 208 blz. Repertorium van alle ambachten op het territorium van het huidige België vanaf de Middeleeuwen tot het einde van de Moderne tijden. De ambachten worden gegroepeerd per stad. Per ambacht worden de reglementen en stichtingscharters opgegeven, de beschermheiligen, de verschillende activiteiten, de blazoenen en de bestaande bibliografie.

2060. HEYRMAN P., Inventaris van het Archief André Vlerick 1919-1990, (Kadoc), Leuven, 2002. Het archief van André Vlerick (1919-1990) omvat onder meer stukken over zijn academische activiteiten aan de Rijksuniversiteit Gent, de oprichting en de werking van het Instituut Professor Vlerick voor Management, evenals over zijn ruimere politieke, economische en maatschappelijke betekenis.

2061. MEERSSEMAN S., Gent van den oudsten tijd tot heden. Registers op het werk van Frans De Potter, (Verhandelingen der Maatschappij voor Geschiedenis en Oudheidkunde, 27), Gent, 2002, 575 blz. De ontsluiting op het achtdelige werk van Frans De Potter over Gent werd opgesplitst in diverse registers: op personennamen, op plaatsnamen en op enkele gekozen the- 


\section{BIBLIOGRAFIE VAN DE GESCHIEDENIS VAN GENT 2001-2002}

mata. Vooraf wordt voldoende duiding gegeven om de registers nuttig te gebruiken en zo makkelijker toegang te hebben tot De Potters levenswerk over Gent. Enkele kritische noten met betrekking tot de bruikbaarheid worden aangereikt in het inleidende artikel van M.C. LALEMAN en D. LIEVOIS, De wetenschappelijke betekenis van Frans De Potters 'Gent. Van den oudsten tijd tot heden (p. 15-24).

2062. OOSTERBOSCH M., Extra Muros, Gandensia in het archief van de Grote Raad, in @ rchieflink, 2, (2002), nr. 2, p. 6-7. Het archief van de Grote Raad in het Rijksarchief van Brussel bevat nog talloze dossiers die door lagere rechtbanken in het kader van een procedure van de Grote Raad in Mechelen waren overgebracht. Dit wordt geillustreerd aan een Gents voorval van 1539 dat voor de schepenen van gedele van Gent en de Raad van Vlaanderen niet werd beslecht, en in beroep bij de Grote Raad terechtkwam.

2063. POELMAN R., Alfabetische index op de doopregisters uit de SintAmanduskapel. Sint-Amandsberg 1730-1796, Sint-Amandsberg, 2000, 230 blz.

2064. POELMAN R., Sint-Amandsberg. Huwelijken 1847-1900, 2002.

2065. SAERENS L., Inventaris van het archief van de familie LammensVerhaegen ca. 1820-1950, (Kadoc), Leuven, 2002. In het archiefbestand Lammens-Verhaegen binnen het Kadoc staat het archief van Arthur Verhaegen (1847-1917) centraal en dit is van belang voor zowel zijn familiale context als voor zijn betekenis als politiek, sociaal en cultureel figuur. Arthur Verhaegen verzamelde ook stukken over Pierre Théodore Verhaegen (1796-1862), Eugène Verhaegen (1820-1878) en Jules Lammens (1822-1908). Het fonds bevat ook het archief van Pierre Verhaegen (1873-1953).

2066. VERBOVEN K., De zogenaamde collectie 'De Bast'. Twintig eeuwen muntgeschiedenis in de collectie van de Gentse Universiteitsbibliotheek. Gent, 2001, $100 \mathrm{blz}$. Catalogus bij de tentoonstelling die enerzijds de rijke collectie munten van de universiteit, waarvan kanunnik M.-J. de Bast (17531825) de grondlegger is, in de kijker wil plaatsen maar anderzijds ook een overzicht wil bieden van 2000 jaren muntgeschiedenis (van 500 v.C. tot 1500 n.C.) Geillustreerd.

\section{Archeologische kronieken}

2067. BLAISING J.M., e.a., Archaeologia Mediaevalis. Kroniek-Chronique, Gent-Brussel/Bruxelles-Namur, 2002, nr. 25, 99 blz. Kroniek over het archeologisch onderzoek in 2001 in België en de aangrenzende regio's. Met medewerking van de Dienst Stadsarcheologie van de Stad Gent. 
2068. LALEMAN M.C., Hospitalen en ziekenzorg in Gent. Een bijdrage van de stadsarcheologie, in Archaeologia Mediaevalis 25. Pré-actes/Introductieteksten, Namur 2002, p. 10. Met verwijzingen naar onderzoek in de SintPietersabdij, middeleeuwse stadswoningen, het Sint-Elisabethbegijnhof, het klooster van de geschoeide karmelieten (Lange Steenstraat/Trommelstraat) en vooral de Bijloke.

2069. LALEMAN M.C., A RAMBAUT, G. STOOPS \& G. VERMEIREN, Archeologisch onderzoek in Sint-Kruis-Winkel (Gent) (O.Vl.), in Archaeologia Mediaevalis, Gent-Brussel/Bruxelles-Namur, 2002, nr. 25, p. 25-26. Met een bondige weergave van de eerste resultaten van archeologisch onderzoek in de Heilig-Kruiskerk en op de voormalige kasteelsite langsheen het huidige Sint-Kruis-Winkeldorp.

2070. LALEMAN M.C., G. STOOPS \& G. VERMEIREN, Archeologisch onderzoek in Gent (O.Vl.), in Archaeologia Mediaevalis, GentBrussel/Bruxelles-Namur, 2002, nr. 25, p. 62-65. Overzicht van het archeologisch terreinonderzoek over 2001 met bijkomende uitbreidingen over de ontwikkeling van de middeleeuwse stad, met de plaats van de Botermarkt in dat urbanisatieproces. Verder worden er bevindingen meegedeeld met betrekking tot het Hof van Gruuthuse aan de Korenlei, het voldersgodshuis aan de SintKristoffelstraat, laatmiddeleeuwse bewoning aan de Veerkaai, het Vleeshuis en de ontwikkeling van de Groentenmarkt, de Sint-Pietersabdij, het Gravensteen en de molensite van de Bourgoyen.

2071. MATTHYS A, Archaeologia Mediaevalis à 25 ans!, in Archaeologia Mediaevalis 25. Préactes (Introductie-teksten, Namur 2002, p. 3-4. Met verwijzingen naar het stadsarcheologisch onderzoek in Gent.

2072. Vondstmeldingen, in Stadsarcheologie. Bodem en monument in Gent, 23, (1999), nr. 1, p. 79-85. Mededeling van archeologische bevindingen en vondsten: wandafwerking in de refter van de Sint-Baafsabdij (Gandastraat), middeleeuwse en postmiddeleeuwse gebouwsporen (Goudenleeuwplein 3), de sokkel en de funderingen van het Groot Kanon (Grootkanonplein), interieurafwerking in de benedenkerk van de Sint-Niklaaskerk (Korenmarkt) en gebouwsporen in de 18de-eeuwse molenromp (Mahatma Gandhistraat). Geillustreerd.

\section{Algemeen}

2073. CHARLES L., Een nieuwe eeuw, in @ rchieflink, 2 (2002), nr. 3, p. 45. Beknopt jaarverslag van de werking van het Stadsarchief over 2001. Geillustreerd. 


\section{BIBLIOGRAFIE VAN DE GESCHIEDENIS VAN GENT 2001-2002}

2074. DHAENE S., G. VANDERHAEGEN \& E. VERAVERBEKE, Het Huis van Alijn, Museum van de dingen die voorbijgaan, in Openbaar Kunstbezit in Vlaanderen, (2001), nr. 3, p. 3-43. Na een beknopte historische schets over het ontstaan en de ontwikkeling van het Sint-Catharinagodshuis of kinderen Alijnshospitaal, tot aan de omvorming tot Museum voor Folklore worden de betrachtingen van het huidige Huis van Alijn voorgesteld en geilllustreerd met voorbeelden uit de museumopstelling, de museumcollectie en een brede waaier aan activiteiten. Geillustreerd.

2075. EVRARD K.A., De Utenhove-stichting en hare uitvloeisels. Catalogus der tentoonstelling, (Stichting Jan Palfijn), Gent, 2001, 72 blz. Catalogus verschenen naar aanleiding van de tentoonstelling georganiseerd door de Jan Palfijnstichting bij gelegenheid van de 800 ste verjaardag van de stichting van het Utenhovehospitaal dat na een kwarteeuw het Bijlokehospitaal zou worden. Geillustreerd.

2076. JANSSENS U., Historische gids voor België, 2002, 320 blz. Met verwijzingen naar Gent. Geillustreerd.

2077. THIELEMANS S., Ontsluiten van cultureel erfgoed - tentoonstellingen maken?, in Mores, 2, (2001), nr. 4, p. 5-8. Met verwijzingen van de nieuwe impulsen onder leiding van de v.z.w. Gent Cultuurstad en gestaafd aan Gentse voorbeelden. Geillustreerd.

2078. VANDAMME L., Op zoek naar particuliere bibliotheken in Vlaanderen, in Vlaanderen, 50, (2001), nr. 5, p. 258-262. Bijdrage in een themanummer gewijd aan particuliere boekenverzamelingen waarin gewezen wordt op de moeilijkheden en op de bronnen die voorhanden zijn bij het reconstrueren en interpreteren van een privé-bibliotheek uit het verleden. Chronologisch overzicht. Ook Gent komt aan bod, vooral dan met de iniatieven van Charles Van Hulthem.

2079. VAN DER HERTEN B., M. VAN MEERTEN en G. VERBEURGT, Sporen in België. 175 jaar spoorwegen, Leuven, 2001, 479 blz. Publicatie, naar aanleiding van de 75ste verjaardag van de NMBS, die de brede waaier van maatschappelijke processen belicht die verbonden zijn met de trein. De auteurs belichten de geschiedenis van de Belgische spoorwegen in de 19de en 20ste eeuw, maar hebben eveneens aandacht voor de Europese context en de technologische, economische, sociale en culturele aspecten. Verwijzingen naar Gent. Geillustreerd.

2080. VANDEWALLE G., De ontwikkeling van de haven van Gent in verband met de economische evolutie van het hinterland, in Het Tijdschrift van Dexiabank, 55, (2001), nr. 217, p. 27-50. Overzicht van de geschiedenis vanaf de Middeleeuwen tot en met de recentste ontwikkelingen, zoals het intensifiëren 


\section{LEEN CHARLES, MARIE CHRISTINE LALEMAN EN VALÉRIE MEILLANDER}

van de industriële activiteiten en van de binnenvaart onder invloed van het besluit van minister Steve Stevaert om de vaargelden af te schaffen. Geillustreerd.

\section{Prehistorie, Romeinse en Merovingische tijden (-)}

2081. BAUTERS L., G. DEVOS \& J. DEVREKER, Pessinus, epitaaf voor een antieke stad, in Monumentenzorg en Cultuurpatrimonium. Jaarverslag van de Provincie Oost-Vlaanderen 2000, Gent, 2001, p. 12-27. Over het archeologisch onderzoek van de Universiteit Gent op deze antieke site in het huidige Turkije, evenals over de ontwikkelingen in onderzoek en resultaten sedert 1966. Geillustreerd.

\section{Middeleeuwen}

2082. BOONE M., Urban Space and Political Conflict in Late Medieval Flanders, in Journal of Interdisciplinary History, XXXII, (2002), nr. 4, p. 621-640. Bijdrage waarin wordt aangenomen dat de invloed van de politieke cultuur op het inrichten van de stedelijke ruimte minstens even belangrijk is als de economische motieven.

2083. CARLIER M., Kinderen van de minne? Bastaarden in het vijftiendeeeuwse Vlaanderen, (Verhandelingen van de Koninklijke Vlaamse Academie van België voor Wetenschappen en Kunsten, Nieuwe Reeks, nr. 3,) Brussel, 2001, 328 blz. Eerste luik in een doctoraatsonderzoek naar onwettigheid waarbij de aandacht uitgaat naar de verschillende actoren ervan, namelijk de natuurlijke ouders, de onwettige kinderen en de maatschappij. Aan de hand van verschillende elementen zoals juridische positie, positie op de arbeidsmarkt, financiën, familiale omstandigheden, maatschappelijke aanvaarding, deelname aan sociale en politieke netwerken poogt de auteur te komen tot een verklaringsmodel voor de aanwezigheid van onwettige kinderen in de Bourgondische Nederlanden. Uitgebreid kritisch apparaat.

2084. CHARLES L., Philips Sersanders, secretaris met liefdesverdriet, in @ rchieflink, 2, (2002), nr. 1, p. 4-5. Over een gedichtje, genoteerd in een handboekje dat door de secretaris van de schepenen van gedele werd bijgehouden en in het Stadsarchief bewaard bleef. De zoektocht naar de mogelijke schrijver leidde tot Philips Sersanders (1422-1451). Geillustreerd.

2085. GUZETTI L., Vrouwen in Venetië en Gent in de late veertiende en de vroege vijftiende eeuw: een vergelijking, in @rchieflink, 2, (2002), nr. 1, p. 67. Relaas van onderzoek in het Gentse Stadsarchief over testamenten van vrouwen uit de late Middeleeuwen, en een poging tot vergelijking tussen Gent en Venezia. Geillustreerd. 
2086. Inventaire archeologique - fiche $n^{\circ} 51$, in Ghendtsche Tydinghen, 31, (2002), nr. 3, p. 128. Heruitgave van een fiche, opgesteld door Henri Pirenne, in de rubriek "Zegels-Staatsarchief, fonds van Sint-Pieters, $\mathrm{n}^{\circ} 18$ - Xe eeuw (941)" over een zegel van Arnulf I, graaf van Vlaanderen.

2087. LARSEN N.- E., Grafematische analyse van een Middelnederlandse tekst. Het grafeemsysteem van de Vroegmiddelnederlandse Statuten van de Gentse Leprozerie uit 1236, Amsterdam, 2001, 369 blz. Grafematische analyse (= de theorie en de methodologie van de analyse van de distinctieve grootheden van de geschreven taal) van én van de oudste, zoniet dé oudste, als origineel overgeleverde niet-literaire tekst in het Nederlands. Uitgebreid kritisch apparaat.

2088. LYON B. \& M. LYON, The Logistics for Edward I's Ill-fated Campaign in Flanders (1297-1298) in Handelingen der Maatschappij voor Geschiedenis en Oudheidkunde te Gent, (2001), nr. LV, p. 77-91. Over voorbereidselen van Edward I tijdens de herfst van 1297 en de winter van 1298 in de militaire campagne tegen Filips de Schone, koning van Frankrijk. De gegevens zijn gebaseerd op het Wardrobe book dat uitleg verschaft over het transport over zee, de bezoldigingen van de soldaten en de zeelui, de voorbereidselen voor het verblijf van Edward in Gent, de bevoorrading in voedsel en wijn, en zo meer.

2089. MAES D., Heerlijkheden en lenen te Drongen en te Baarle (2), in Dronghine, Jaarboek, 2002, p. 27-52.

2090. VAN ACKER K.G., De heren van Munte in een bewogen tijd: 9621150, in Land van Rode, 29, (2001), nr. 116, p. 14-36. Met informatie over Arnold van Munte, abt van de Sint-Pietersabdij te Gent en over de burggraaf van Gent.

2091. VAN CAENEGEM R. (dir.), 1302 Feiten \& mythen van de Guldensporenslag, (Mercatorfonds), Antwerpen, 2002, $301 \mathrm{blz}$. Verschillende auteurs lichten aspecten van de historische gebeurtenis in zijn globale context en van de beeldvorming over dit gebeuren toe. M. BOONE behandelt de verstedelijkte samenleving in het graafschap Vlaanderen (p. 26-76). Het Capetingische koningschap in de 13de eeuw wordt toegelicht door E. BOURNAZEL (p. 78-103). D. HEIRBAUT verdiept zich in het juridische kader, de instellingen en het recht in Vlaanderen omstreeks 1302 (p. 106-131). Waar en hoe vond de slag van Kortrijk plaats? P. DESPRIET schetst een geactualiseerde visie daaromtrent (p. 158-168). De voorstelling van de Guldensporenslag wordt toegelicht door B. CARDON en B. STROOBANTS (p. 170-188). De beeldvorming over 1302 wordt besproken door J. TOLLEBEEK (p. 194-236), terwijl S. DAUCHY de weergave over dit gebeuren in Franse handboeken heeft geanalyseerd (p. 240-259). Een laatste hoofdstuk, 
van de hand van L. DEVLIEGHER, heeft het over de omstreden kist van Oxford (p. 262-282). De uitgave sluit af met een genealogie van de graven van Vlaanderen en met een register op naam. Geillustreerd.

2092. VAN HAMME H., Stedelijk particularisme versus vorstelijke centralisatie en hun impact op de bestraffing van criminaliteit in het vijftiende-eeuwse Gent (ca. 1419-ca. 1480), in Handelingen der Maatschappij voor Geschiedenis en Oudheidkunde te Gent, (2001), nr. LV, p. 135-178. Vergelijkend onderzoek naar de activiteiten van de stedelijke zoen - en de grafelijke strafrechtbank in Gent binnen de context van de Bourgondische staatsvorming. Het gaat hier om de paisierders of stedelijke verzoeners enerzijds en de schepenen van de Keure, die vonnisten als grafelijke rechters, anderszijds. De auteur besteedt vooral aandacht aan de evolutie van het aantal verzoeningen, straffen en composities in een periode van tanend stedelijk particularisme.

2093. VERBRUGGEN J.F. \& R. FALTER, 1302. Opstand in Vlaanderen, 2002, 278 blz. De slag van 11 juli 1032 in Kortrijk binnen de context van opstand, revolutie en omwenteling.

\section{Moderne Tijden}

2094. BARBRY R., De Gentse armenschool voor jongens. De kulders in de zeventiende eeuw, in @ rchieflink, 2, (2002), nr.'1, p. 1-2. Over de in 1628 opgerichte armenschool voor jongens en de inlichtingen die in Reeks LXXXIII van het Gentse Stadsarchief daarover te vinden zijn. Geïllustreerd.

2095. BRAEKMAN W.L., Het Gaverse en het Oudburgse Mariakerke in vroeger eeuwen: een moeilijke relatie, in Heemkundige Kring Marka, Jaarboek 2002, p.81-100. Centraal in dit artikel over de verschillende lenen te Mariakerke onder het Ancien Régime staat de moeilijke relatie tussen de heer van Vaernewijck en de burggraaf van de Oudburg.

2096. BUSSELS S., Een onuitgevoerde intrede in Gent van Justus de Harduyn en David Van der Linden in Handelingen der Maatschappij voor Geschiedenis en Oudheidkunde te Gent, (2001), nr. LV, p. 237-249. Bespreking van de onuitgevoerde intrede van de nieuwe gouverneur-generaal don Ferdinand in Gent in 1635, waarbij het stadsbestuur opteerde voor de intrede van de jezuïet Becanus die wél de kwaliteiten van de Spaanse kroon beschreef en het katholieke geloof vooropstelde, maar geen beschrijving gaf van de armoedige toestand van de Spaanse Nederlanden zoals in de onuitgevoerde intrede van De Harduyn en Van der Linden wél het geval was.

2097. BUSSELS S. \& B.VAN OOSTVELDT, De traditie van de tableaux vivants bij de plechtige intochten in de Zuidelijke Nederlanden, in Tijdschrift 
voor Geschiedenis, 115, (2002), nr. 2, p.166-180. Aan de hand van enkele concrete voorbeelden wordt aangetoond hoe gaandeweg vanaf het einde van de 15 de eeuw tot het begin van de 17 de eeuw tableaux vivants evolueren van een communicatiemiddel tussen stad en vorst naar een triomftocht die de vorstelijke macht tentoonspreidde.

2098. CASSIMAN P., Openbare ambten te Baarle. Burgemeester, Schepene, Bailliu, Meier, Amman, Ontvanger, Capiteyn, Officier, Tamboer, Praeter, in Dronghine, Jaarboek, 2002, p. 41-45.

2099. DAMBRUYNE J., Mensen en centen. Het 16de-eeuwse Gent in demografische en economisch perspectief, (Verhandelingen der Maatschappij voor Geschiedenis en Oudheidkunde, XXVI), Gent, 2001, 446 blz. Het gaat om het eerste luik van een doctoraal proefschrift, met name de economisch-demografische studie van corporatieve middengroepen in het 16de-eeuwse Gent. De publicatie is opgebouwd in twee delen. In een eerste deel wordt de stedelijke economische conjunctuur toegelicht, zowel vanuit een demografische als vanuit een economische invalshoek. Gent wordt hier ook vergeleken met andere Zuid-Nederlandse en Europese steden. In een tweede deel worden de conjunctuurbewegingen van drie economische sectoren verder geanalyseerd, de textielnijverheid, de graanhandel en de transportsector. Ondersteund met grafieken, kaarten en bijlagen.

2100. DECEULAER H., De breigoedsector in de Zuidelijke Nederlanden in de zeventiende en achttiende eeuw: tussen consumptie, politiek, gender en technologie in Tijdschrift voor Sociale Geschiedenis, 28, (2002), nr. 1, p. 1-13. In deze bijdrage wil de auteur de relatie onderzoeken tussen de nieuwe technieken, met name de breigetouwen die vooral door de mannen werden bediend versus de manuele vaardigheden, namelijk het handbreien door de vrouwen. De verspreiding van het breigetouw in de Zuidelijke Nederlanden wordt in een sociale, culturele en politieke context gesitueerd. Voorbeelden uit Gent.

2101. DESEIJN G., Aan 't lijntje houden. De bargie, in Tijdschrift voor Industriële Cultuur, 20, (2002), nr. 2, Cahier 22/B, p. 23-33. Bijdrage over de barge, het comfortabele luxeschip dat in de 17 de en 18de eeuw tussen Brugge en Gent vaarde, in een themanummer over de binnenscheepvaart, uitgegeven ter gelegenheid van de tentoonstelling in het MIAT IJzeren schippers op houten schepen.

2102. DE SMET S., De Burgerlijke Rechtspraak voor de Gentse Schepenbank van de Keure. Organisatie, Personeel, Procedure en Archief in Handelingen der Maatschappij voor Geschiedenis en Oudheidkunde te Gent, (2001), nr. LV, p. 251-295. Artikel gebaseerd op een eindverhandeling voor de opleiding archivistiek en hedendaags documentbeheer, waarbij een analyse wordt doorgevoerd van het archief van de burgerlijke rechtspraak voor de 
Gentse schepenbank van de keure in het Gentse Stadsarchief. De verhandeling is toegespitst op de $18 \mathrm{de}$ eeuw en in het artikel is er vooral aandacht voor de instellingenstudie. De auteur schetst wie er allemaal bij de rechtspraak betrokken is, hoe de procedure verliep en bespreekt tenslotte de voornaamste archiefreeksen naar hun functie, inhoud, waarde en ontsluitingsmogelijkheden.

2103. DE WILDE J.R.J., Het faict van tooverie in Laarne (1607-1608): enkele feiten en bedenkingen, in Castellum, XVIII, (2001), nr. 4, p. 3-32. Het artikel biedt een status quaestionis in het onderzoek naar de heksenprocessen in Laarne, evenals de beschikbare archivalia en een schets van de situatie in de omringende regio. De auteur probeert na te gaan of het hier ging om geïsoleerde gevallen en/of de processen eenzelfde stramien vertonen met het algemeen patroon van de heksenvervolgingen in Vlaanderen. Korte schets van een aantal gevallen te Gent.

2104. LEDERER D., De cultuurgeschiedenis van de zelfdoding in Vlaanderen: een uitdaging, in @rchieflink, 2, (2002), nr. 2, p. 4-5. Samenvatting van een onderzoek naar de zelfdoding in het Heilig Roomse Rijk in de periode van 1495 tot 1806 . Een eerste reeks bevindingen handelt over de verschillen in wettelijke procedures en gewoonterecht tussen Vlaanderen en Gent ten opzichte van wat bijvoorbeeld in Centraal-Europa gangbaar was. Een tweede reeks bevindingen geeft mogelijkheden aan tot een meer diepgaande analyse van de beschikbare bronnen.

2105. LENDERS P., Overheid en geneeskunde in de Habsburgse Nederlanden en het Prinsbisdom Luik, in Standen en Landen, CIII, (2001), 199 blz. In de Zuidelijke Nederlanden en in het Prinsbisdom Luik heeft de overheid het toezicht op de uitoefening van de geneeskunde steeds tot haar opdracht gerekend. Deze studie wil een synthese brengen van de geneeskundige zorgenverstrekking en een licht werpen op de mensen uit de dagelijkse praktijk. Vooral de betrekkingen tussen de verantwoordelijke overheden in de Habsburgse Nederlanden en het Prinsbisdom Luik en de medische dienstverleners en het toezicht op de opleiding komen aan bod. Telkens wordt ook de Gentse situatie belicht.

2106. SCHEPENS E., Testamenten, schenkingen en staten van goederen van enkele begijnen gesteed in het begijnhof Onze-Lieve-Vrouw ter Hooie, in Ghendtsche Tydinghen, 31, (2002), nr. 2, p. 105-112; nr. 3, p. 168-172; nr. 4, p. 222-229.

2107. TONDAT R., De geboorteplaats van Keizer Karel in Handelingen der Maatschappij voor Geschiedenis en Oudheidkunde te Gent, (2001), nr. LV, p. 457-461. Verder verhaal in de discussie over de geboorteplaats van Keizer Karel, waarbij voor Eeklo wordt geopteerd. 
2108. VERMEIR R., Romano Tondats betoog van naderbij bekeken in Handelingen der Maatschappij voor Geschiedenis en Oudheidkunde te Gent, (2001), nr. LV, p. 463-466. Repliek op het artikel van Romano Tondat in de dezelfde uitgave, waarbij de stelling als zou Keizer Karel in Eeklo zou zijn geboren, teniet wordt gedaan.

\section{Hedendaagse tijd}

2109. BACKS J., Mortality in Ghent, 1850-1950, in Belgisch Tijdschrift voor Nieuwste Geschiedenis, XXXI, (2001), nr. 3-4, p. 529-556. Sociale analyse van de dood aan de hand van de beroepsaanduidingen in de overlijdensakten van de burgerlijke stand. Daaruit blijkt dat er een duidelijke sociale ongelijkheid bestaat ten opzichte van de dood wat nog toenam naar het einde van de 19de eeuw.

2110. CASSIMAN P., Het gemeentebestuur te Drongen tussen 1795 en 1976, in Dronghine, Jaarboek, 2002, p. 149-166.

2111. CONVENTS G., De Belle Epoque in kleur. Kinemacolor: op-en ondergang van de eerste kleurenfilms in België 1911-1913, in Tijdschrift voor Industriële Cultuur, 79, (2002), nr. 3, p. 1-41. Sinds 1976 is er sprake van de nieuwe filmhistoriografie. Eén van de gevolgen van deze nieuwe richting is de herwaardering van kleur in de stille film. Tijdens de Belle Epoque zelf bestond in alle geledingen van de maatschappij een grote fascinatie voor de technologie die toeliet fotografie en cinematografie van kleur te voorzien. Heel wat Gentse accenten. Geillustreerd.

2112. DE CLOET F., De Gentse Atletiek tijdens het Interbellum, in Interbellum, 21, (2001), nr. 5, p. 11-15. Korte bijdrage over de oudste atletiekvereniging van België, ARAG-KAA Gent, die een ongekende bloei kende in de jaren '20 en '30. Geillustreerd.

2113. DERWAEL J., 'Il vaut mieux prendre souci de la qualité que de la quantité...' De sociale achtergrond van de Gentse sportverenigingen op het einde van de 19de eeuw en het begin van de 20ste eeuw in Handelingen der Maatschappij voor Geschiedenis en Oudheidkunde te Gent, (2001), nr. LV, p. 413-456. De auteur schetst enkele facetten van de sociale geschiedenis van het fenomeen sport, zoals toetredingsvoorwaarden, sociale achtergrond van de bestuursleden, de banden tussen de sportclubs, de ligging van de diverse clublokalen en de spanningen tussen de diverse roeiclubs.

2114. DESEIJN G., "La misère publique résume toute l'origine de l'épidémie...". De belangrijke rol van de Gentse Société de Médecine voor de arbeidersklasse, in Tijdschrift voor Industriële cultuur, 20, (2002), nr. 1, p. 30-48. 
Deze maatschappij, gesticht in 1834 en waarvan een aantal eminente artsen zoals Dr. Burggraeve, Dr. Mareska, Dr. Kluyskens en Dr. Guislain lid waren, lag aan de basis van de verbetering van de levensomstandigheden van de Gentse arbeiders en vooral van de huisvesting. In het Bulletin van de Société lag de nadruk aanvankelijk op de geesteszieken, maar naderhand kregen de talrijke epidemieën die de arbeidersklassen teisterden, steeds meer belangstelling.

2115. DEVRIEZE A. \& E. VANHAUTE, Working-class girls. The life-courses of 33 women cotton workers in Ghent around 1900 in Belgisch Tijdschrift voor Nieuwste Geschiedenis, XXXI, (2001), nr. 3-4, p. 557-578. Levensloopanalyse waarbij aan de hand van bevolkingsboeken en loonregisters het leven en het werk van drieëndertig Gentse textielarbeidsters van de weverij A. Voortman in kaart worden gebracht.

2116. DE WAELE M., Koopkracht en levensstandaard in België \& Vlaanderen tussen 1800 en 1990, in Tijdschrift voor Industriële cultuur, 20, (2002), nr. 1, p. 2-29. Studie van de bestedingspatronen van de gemiddelde Belg en Vlaming in de 19de en 20ste eeuw, vooral gebaseerd op de budgetenquêtes die in België met een aanzienlijke regelmaat werden georganiseerd. Sterke klemtoon op de situatie van de Gentse textielarbeiders en van de huisarbeiders op het platteland.. De auteur probeert vooral duidelijk te maken dat de evolutie van een agrarisch-ambachtelijke naar een industriële maatschappij langzaam en ongelijk verlopen is.

2117. DE WAELE M., De strijd om de citadel. Frankrijk en de vernederlandsing van de Gentse Universiteit 1918-1930, in Belgisch Tijdschrift voor Nieuwste Geschiedenis, XXXII, (2002), nr. 1-2, p. 153-193. Overzicht van de gebeurtenissen, vanaf de Eerste Wereldoorlog tot 1930, die geleid hebben tot de vernederlandsing van de Universiteit en de reacties van Frankrijk op deze ontwikkelingen.

2118. DILLEN K., From one textile centre to another. Migrations from the district of Ghent to the city of Armentières (France) during the second half of the 19th century, in Belgisch.Tijdschrift voor Nieuwste Geschiedenis, XXXI, (2001), nr. 3-4, p. 431-452. Uit het gevoerde onderzoek naar de beweegredenen van 19de-eeuwse migranten blijkt dat migratie niet altijd plaatsvond omwille van economische motieven of omwille van een ontworteling van de rurale samenleving, maar dat ook sociale netwerken een aanzienlijke beweegreden vormden.

2119. HEIRMAN M., Onzichtbare slachtoffers. Een micro-onderzoek naar kindermoord in de negentiende eeuw in Oost-Vlaanderen op basis van assisendossiers, in Handelingen der Maatschappij voor Geschiedenis en Oudheidkunde te Gent, (2001), nr. LV, p. 347-367. De auteur schetst de meest 
voorkomende omstandigheden voor het plegen van een kindermoord en poogt te komen tot een eigen verklaringsmodel, gebaseerd op een micro-onderzoek van de regio Oost-Vlaanderen in de 19de eeuw aan de hand van de kindermoorddossiers van het Oost-Vlaamse Hof van Assisen

2120. HERMAN S., De grenzen van seksueel geweld. Schuld en schande in Vlaanderen tijdens de negentiende eeuw in Tijdschrift voor Sociale Geschiedenis, 28, (2002), nr. 1, p. 57-80. Onderzoek naar de mentaliteitsgeschiedenis van seksueel geweld, gebaseerd op de strafdossiers van het hof van assisen. Er wordt aandacht besteed aan de houding tegenover seksueel geweld in het dagelijkse leven, aan de juridische aspecten, aan de relatie tussen dader en slachtoffer, aan de reacties van de dader enerzijds en van het slachtoffer anderzijds. Voorbeelden uit het Gentse.

2121. MAES D., Zij overleefden net niet het einde van WO I in Dronghine, Jaarboek, 2002, p. 51-52. Lijst van de eenentwintig militairen vermeld in de overlijdenregisters van Baarle die sneuvelden tijdens het eindoffensief.

2122. MUSSCHOOT D., Wij gaan naar Amerika. Vlaamse landverhuizers naar de nieuwe wereld, 1850-1930, Tielt, 2002, 247 blz. De auteur probeert een beeld op te hangen van de omstandigheden waarin zowat 150.000 landgenoten de overtocht waagden naar de nieuwe wereld. Het boek is gebaseerd op tientallen interviews van nabestaanden, brieven, dagboeken, archiefmateriaal, en zo meer. Ook Gentse getuigenissen. Geillustreerd.

2123. VAN HEESVELDE P., Luchtaanvallen en bombardementen op Gentse spoorinfrastructuur tijdens de Tweede Wereldoorlog, in Jaarboek De OostOudburg, (2001), nr. 38, p. 39-62. Bedenkingen over de transportcampagne van de geallieerden, die trouwens een ruimer deel van het netwerk voorzag dan enkel het verkeersknooppunt rond Gent.

2124. VAN MOLLE L. \& P. HEYRMAN (red.), Vrouwenzaken-Zakenvrouwen. Facetten van vrouwelijk zelfstandig ondernemerschap in Vlaanderen, 1800-2000, (Bijdrage Museum van de Vlaamse sociale strijd, $\mathrm{nr} .18$ ), Gent-Leuven, 2001, $203 \mathrm{blz}$. Studie, waaraan verscheidene auteurs meewerkten, over de zelfstandige arbeid van vrouwen in het niet-rurale milieu van Vlaanderen. De inleidende hoofdstukken bevatten behalve een historiografische doorlichting een behandeling van het juridisch statuut en een kwalitatieve duiding van de vrouwelijke zelfstandige arbeid in de 19de en de 20 ste eeuw. In een volgende deel worden de beroepen zelf behandeld, onder meer in de kleinhandel en de horeca, in de textielsector, in de medische en de juridische sector, in de kunstwereld, in de bedrijven. Met het hoofdstuk 'hefbomen voor ontvoogding en een bijdrage over het CMBV sluit dit standaardwerk af. Met index op persoonsnamen. Geillustreerd. 


\section{LEEN CHARLES, MARIE CHRISTINE LALEMAN EN VALÉRIE MEILLANDER}

2125. VAN RYSSEL D., 19de-eeuwse vondelingen kregen rare namen, in Ghendtsche Tydinghen, 31, (2002), nr. 5, p. 278-289. Over enkele aspecten van de vondelingen in de 19de eeuw zoals kledij, namen, uitbesteding, het rolleke, het weeshuis.

2126. VERMEULEN A, Madame Simonnet en haar school 1880-2000, (School Simonnet), Sint-Martens-Latem, 2001. De auteur belicht de figuur van mevrouw Simonnet voor de sociale ontwikkeling van Sint-MartensLatem, en vooral de betekenis van de school. Geillustreerd.

2127. WUYTS E., Wereldtentoonstelling Gent 1913 in metaal vereeuwigd: een iconografische case-study van expomedailles in Handelingen der Maatschappij voor Geschiedenis en Oudheidkunde te Gent, (2001), nr. LV, p. 369-412. Schets van de historische context waarin de medailles zijn ontstaan en onderzoek naar de conceptie, receptie en betekenis van enkele representatieve stukken uit de medailleproductie van de Wereldtentoonstelling van 1913, waarbij de auteur vooral de relevantie van deze voorwerpen voor het historisch onderzoek wil beklemtonen.

\section{Industriële archeologie}

2128. BAECK M. \& J. DE PLUS, Geëmailleerde reclameplaten in Belgïe, (V.Z.W. Interbellum), Gent, 2001, 112 blz. Historisch overzicht, sociaal-economische context en productiegeschiedenis van de geëmailleerde reclameplaat. Geillustreerd.

2129. DE HERDT R., Mondelinge geschiedenis in technische en industriële musea. De weg naar een nieuwe bron voor inventarisatie en studie van oudere technieken, in Oostvlaamse Zanten, 76, (2001), nr. 3, p. 204-212. Ondersteund door ervaringen in het Gentse Museum voor Industriële Archeologie en Textiel of MIAT. Geillustreerd.

2130. DELCART A., Mosterd specerijkelijk, in Mosterd specerijkelijk, (Museum voor Industriële Archeologie en Textiel), Gent, 2001, p. 5-19. Verschillende aspecten van de mosterdbereiding komen aan bod, evenals de betekenis van mosterd voor de geneeskunde en de ecologische landbouw. Geillustreerd.

2131. DESEIJN G., De technische gebouwen bewaren, in Oostvlaamse Zanten, 76 (2001), nr. 3, p. 188-197. Met meer uitgebreide toelichtingen over Antwerpen en vooral Gent. Geillustreerd.

2132. DESEIJN G., Een industrie...? Van mosterdventer tot commerce, in Mosterd specerijkelijk, (Museum voor Industriële Archeologie en Textiel), Gent, 2001, p. 20-35. Geillustreerd. 
2133. DESEIJN G., "Je crée un second Manchester...!" Deel twee. Vergelijkende inboedelbeschrijving van de technische uitrusting van enkele vroege Gentse katoenfabrieken, in Tijdschrift voor Industriële Cultuur, (2001), nr. 4, p. 24-38. De openbare verkoop van de katoenfabriek GuinardBauwens in 1832 en de boedelbeschrijving van het bedrijf van 1830-1833 vormen het uitgangspunt van een bijdrage over het functioneren van de katoenfabrieken in het 19de-eeuwse Gent en de betekenis van Lieven Bauwens en Jacques Guinard. De bedrijven uit die periode worden gesitueerd op het plan van Saurel van 1841. Geillustreerd.

2134. DEVRIESE L. \& R. MOREAU, Van vroege beluiken naar laat vertier, in Tijdschrift voor Industriële cultuur, 19, (2001), nr. 3, p. 1-50. Themanummer gewijd aan de vroegste geschiedenis van de Gentse arbeidersbeluiken, met onder andere aandacht voor het militaire logement (en later beluik) aan de Minnemeers, de beluikenconcentratie in de Gentse Overscheldewijk in de $18 \mathrm{de}$ en vroege $19 \mathrm{de}$ eeuw, enkele verdwenen beluiken aan de Veerstraat, de vroegere Mortierstraat, de Doornsteeg en de Apostelstraat en de beluiken die enkele vooraanstaande architecten verwezenlijkt hadden zoals Louis Roelandt en de familie Van de Capelle. Geillustreerd.

2135. MANESSE M., De electriciteitsmaatschappij van Mariakerke in Heemkundige Kring Marka, Jaarboek 2002, p. 53-80. Bijdrage met betrekking tot de pioniersperiode van de elektriciteitsverdeling in Mariakerke en met bijzondere aandacht voor de openbare verlichting.

2136. TAYMANS H., Een standbeeld en medailles voor Lieven Bauwens, in Jaarboek van het Europees Genootschap voor Munt- en Penningkunde, (2001), p. 161-186. Aandacht voor de medailles die vervaardigd werden door V. Lemaire bij de inhuldiging van het standbeeld van Lieven Bauwens. Enkele brieven van V. Lemaire aan het Gentse stadsbestuur zijn illustratief voor de persoonlijkheid van de ontwerper. Ook de controversiële levensloop van Bauwens en twee recentere medailles worden toegelicht. Geíllustreerd.

2137. VAN GANSBEKE J., De Drongense textielveredelingsfabriek Alsberghe-Van Oost (1878-1978), in Dronghine, Jaarboek, 2002, p.1-25.

2138. VIAENE P., De verzamelaar en de geschiedenis van de technieken. Enkele persoonlijke stellingnamen, in Oostvlaamse Zanten, 76, (2001), nr. 3, p. 198-203. Met verwijzing naar een aantal Gentse voorbeelden. Geillustreerd. 


\section{Kerkgeschiedenis, kloosters}

2139. DECLERCQ G., Een Karolingisch lekenambt in Gent. Einhard en de Gentse abdijen van Sint-Pieters en Sint-Baafs, in Handelingen der Maatschappij voor Geschiedenis en Oudheidkunde te Gent, (2001), nr. LV, p. 37-76. Vernieuwde visie en kritische benadering van het bronnenmateriaal dat tekenend was voor de relatie tussen lekenabt Einhard en de beide Gentse abdijen. Dat bronnenmateriaal werd reeds in 1926 door F.L. Ganshof verzameld. Niet alleen de schriftelijke bronnen worden op een andere manier benaderd, onder tussen was ook de geschiedenis van de twee abdijen aan nieuwe inzichten en interpretaties onderhevig, wat eveneens voor de kennis van het optreden van Einhard in Gent van belang blijkt.

2140. MAES D., Kaart met de bezittingen van de Drongense Norbertijnerabdij uit 1743, in Dronghine, Jaarboek, 2002, p.71-100. Studie van de gerestaureerde kaart die zich in het Stadsarchief Gent bevindt, gemaakt door gezworen landmeter J. De Deken in opdracht van de abt van de abdij van Drongen, Antonius de Stoop. De eigendommen van de abdij worden gesitueerd op de Popp-kaart van omstreeks 1830.

2141. MAZEURE N., Het 'Chronicon' van Johannes van Tielrode: een Baafse kruisbestuiving tussen historiografie en diplomatisch bronnenmateriaal in Handelingen der Maatschappij voor Geschiedenis en Oudheidkunde te Gent, (2001), nr. LV, p. 93-134. De auteur probeert na te gaan op welke manier het verleden en het aanwezige bronnenmateriaal door monnik Johannes van Tielrode verwerkt werd tot een verhalende bron, het chronicon, een mengeling van wereldgeschiedenis en lokale kloostergeschiedenis, waarin feit en fictie door elkaar lopen. Het doel van de bijdrage is niet de authenticiteit van de stukken na te gaan, maar situeert zich eerder op het vlak van de subjectieve verhalende presentatie van de feiten.

2142. PAS P., De Gentse abdijen rond het jaar duizend, een situatieschets, in Jaarboek De Oost-Oudburg, (2001), nr. 38, p. 5-24. De Gentse abdijen maken omstreeks het jaar 1000 gebruik van de chaotische situatie binnen het Vaticaan om volledig hun eigen weg te gaan.

2143. VANDERPUTTEN S., "Tot nut van de zonen van deze abdij". Monastieke geschiedschrijving tot het einde van de vijftiende eeuw, in Trajecta, 10, (2001), nr. 3, p. 193-208. De auteur schetst hoe monastieke historiografie in hoofdzaak terug te voeren is tot twee basisprincipes: de zoektocht naar een eigen historische identiteit en de creatie van een zelfbeeld waardoor men zich wenst te profileren ten opzichte van de buitenwereld. Verwijzingen naar de Gentse Sint-Pietersabdij. Geillustreerd. 


\section{BIBLIOGRAFIE VAN DE GESCHIEDENIS VAN GENT 2001-2002}

\section{Gebouwen, monumenten, stadsbeeld}

2144. BAILLIEUL B., Wandelen in de wijk Muide-Meulestede, Gent, 2002, $56 \mathrm{blz}$. Achtereenvolgens komen een aantal thema's aan bod zoals de ligging van deze noordelijke stadswijk, een historisch overzicht, haven, onderwijs, fabrieken, sociale huisvestingsprojecten, syndicalisme, de molens en een wandeling langs de oude weg naar Meulestede. Geïllustreerd.

2145. BOERJAN G., Mariakerke. Het Kerkhof. Bisschoppengalerij. Behoud van het funerair patrimonium, in Heemkundige Kring Marka, Jaarboek 2001, p. 5-29. Enkele toelichtingen over de groei van het kerkhof van Mariakerke, onder meer tengevolge van de kerkhofkwestie in de jaren ' 60 en '70 van de 19de eeuw. Aandacht voor enkele bijzondere grafmonumenten, voor de constructie van de bischoppengalerij en de huidige toestand van het gebouw.

2146. BROES K., De tredmolen. Een onderbelichte molensoort in Molenecho's, XXX, (2002), nr. 3, themanummers 10, p. 116-183. De auteur schetst de ontstaansgeschiedenis van de tredmolen en bestudeert dan vooral de westerse toepassingen ervan zoals de tredmolenlier of de tredmolenkraan. De auteur baseert de indeling van de teksten vooral op de analyse van het beeldmateriaal. Ook de Gentse kranen op de Kraanlei en aan de Lievebrug komen ter sprake, evenals de kraankinderen. Geillustreerd.

2147. CALLEBAUT N., Het kasteel Vilain en het Rattendaelepark, in Land van Rode, 29, (2001), nr. 116, p. 6-8.

2148. CELIS M., Waar tijd van geen tel is: de vakafdeling funerair erfgoed, in Monumenten \& Landschappen, 21, (2002), nr. 1, p. 20-45. In een toelichting over de afdeling funerair erfgoed van de Administratie Monumenten en Landschappen van het Vlaamse Gewest komen diverse voorbeelden aan bod. Zo wordt er ook verwezen naar de drie Gentse begraafplaatsen die in 1996 werden beschermd, met name het Campo Santo op de Kapelleberg in SintAmandsberg, de Westerbegraafplaats aan de Palinghuizen en het kerkhof bij de Onze-Lieve-Vrouw-Geboortekerk in Mariakerke. De bijdrage gaat ook in op problemen van verval en restauratie van onder meer graftekens, grafmonumenten en kerkhofkapellen. Geillustreerd.

2149. COENE A., Kaartblad 22 Gand door het militair cartografisch instituut gepubliceerd in 1894; schaal 1:40000, in Ghendtsche Tydinghen, 31, (2002), nr. 3, p. 129-133. Over de productie van een topografische kaart 1:20.000 en 1:40.000 door het toenmalige Dépôt de la Guerre van 1860 tot 1873.

2150. COENE A., Het Plan van Gend gemeeten en gegraveerd in 'tjaer 1796 door G. Goethals, in Ghendtsche Tydinghen, 30, (2001), nr. 5, p. 299-304. Dit 


\section{LEEN CHARLES, MARIE CHRISTINE LALEMAN EN VALÉRIE MEILLANDER}

plan wordt nog steeds aanzien als een historisch betrouwbare plattegrond voor het Gent van het Ancien Régime, opgevat als een utilitair stratenplan.

2151. COENE A., Het plan van Gent gekarteerd door Vandermaelen (18461854) en de werkwereld omstreeks 1850, in Ghendtsche Tydinghen, 31, (2002), nr. 2, p. 92-96.

2152. COGEN H., Urbanisatie in de 19de en 20ste eeuw tussen Kortrijksepoortstraat en Sint-Pietersnieuwstraat, in G.O.V.-Heraut, 37, (2001), nr. 1, p. 4-13. Geillustreerd.

2153. DE KEYZER L., Het Gravensteen, Gent. Verhalen achter de stenen, Gent-Amsterdam, 2002, 64 blz. Schetsen van een bezoek aan het Gravensteen waarbij de auteur eerder de nadruk poogt te leggen op het menselijke leven binnen die oude muren dan wel op de architectonische betekenis van het monument. Geillustreerd met foto's door M. Hendryckx.

2154. DENEWET L., Integratie van molens in Vlaamse landinrichtingsprojecten, in Molenecho's, 30, (2002), nr. 2, p. 64-79. Eén van de besproken projecten is de integratie van de Hoosmolen in het natuurinrichtingsproject Bourgoyen-Ossemeersen. Deze poldermolen uit 1702 stond heel lang in voor de ontwatering van het gebied.

2155. DENEWET L., Vier koperwatermolens in en rond Gent, in Molenecho's, 29, (2001), nr. 3, p. 142-151. In en rond Gent bestonden er verschillende koperwatermolens die allemaal in dezelfde periode (16401650) aangevraagd en opgericht werden door eenzelfde persoon, met name Jacques van Laerebeke uit Gent. Hij bekwam daartoe twee vorstelijke octrooien.

2156. DERUELLE M.I.J., Gentse gevels der barokperiode, in Ghendtsche Tydinghen, 31, (2002), nr. 3, p. 158-167. Bijdrage die in september-oktober 1934 verscheen in het ondertussen verdwenen tijdschrift Kunst.

2157. DEVOS P., Gent. Het glas-in-lood van de Sint-Baafskathedraal onderzocht, in Monumentenzorg en Cultuurpatrimonium. Jaarverslag van de Provincie Oost-Vlaanderen 2000, Gent, 2001, p. 155-159. Weergave van onderzoeksresultaten die A. RAMBAUT verzamelde over de glas-in-loodramen in het koor van de Sint-Baafskathedraal, hoofdzakelijk uit de tweede helft van de 19 de eeuw. Geillustreerd.

2158. DEVOS P., Gent. Kunsthistorisch onderzoek naar aanleiding van stabiliteitsproblemen in het koor van de Sint-Baafskathedraal in Monumentenzorg en Cultuurpatrimonium. Jaarverslag van de Provincie Oost-Vlaanderen 2000, Gent, 2001, p. 150-154. Over de gebreken die het 
bouwkundige verval van de kerk in de hand werken en door restauratie moeten worden aangepakt. Geillustreerd.

2159. DEVOS P., Gent. Onderzoek naar de polychromie van de SintNiklaaskerk, in Monumentenzorg en Cultuurpatrimonium. Jaarverslag van de Provincie Oost-Vlaanderen 2000, Gent, 2001, p. 160-166. Weergave van het onderzoek en de resultaten die A. BOTTE, A MALYSTER, E. NYS, T. RAYMAKERS, G. REYNIERS onder leiding van H. VANDENBORRE verzamelden over de polychrome afwerking van de benedenkerk. Geillustreerd.

2160. DEVRIESE L., Een kleine geschiedenis van de rooilijn...of: hoe het Gentse centrum (bijna) zijn middeleeuws karakter verloor, in GOV-Heraut, 37, (2002), nr. 2, p. 3-14. Een verkenning naar de invloed van de rooilijnpolitiek op het Gentse stadsbeeld. Het middeleeuwse stratenpatroon bleef nog in grote mate bewaard.

2161. DEVRIESE L., De Waterwijk in Gent. Een 14de-eeuws stadsdeel komt tot stand, in Stadsarcheologie. Bodem en monument in Gent, 23, (1999), nr. 1, p. 14-41. Ontwikkeling van de huizenblokken binnen de z.g. Waterwijk na de verkaveling in de 14de eeuw en waarbij de 14de-eeuwse perceelsindeling grotendeels kon worden gereconstrueerd. De bijdrage gaat onder meer ook dieper in op bepaalde detailaspecten zoals een galerij aan de Ottogracht, een put aan de Oudevest en de inplanting van de Baudelo-abdij. Geillustreerd.

2162. DE VUYST W. \& G. EVERAERT, De handelsbeurs. De metamorfoses van de Gentse hoofdwacht (18de - begin 20ste eeuw) in Handelingen der Maatschappij voor Geschiedenis en Oudheidkunde te Gent, (2001), nr. LV, p. 297-346. Overzicht van de bouwgeschiedenis van de hoofdwacht en van de rest van het gebouwencomplex van de voormalige Handelsbeurs, aan de Kouter. Geillustreerd.

2163. D'HOLLANDER J., Een reuzenspeeldoos. De oudst functionerende voorzaat van de cilinderspeeldozen op het Gentse Belfort?, in Clocke Roeland. Nieuws van de Gentse beiaardkring, 5, (2001), nr. 4, p. 2-7. Gent speelde een toonaangevende rol in de vroege ontwikkeling van het trommelspeelwerk en de beiaard. Geillustreerd.

2164. DIERKENS A. \& B. MIHAIL, Kerk, katholieken en kunst. Onderzoek, in Kadoc Nieuwsbrief, (2002), nr. 3, p. 20-24. Beknopte beschouwing over de studie van de neogotiek, met verwijzing naar het werk van het Bethunianum rond de archieven van Jean Baptiste Bethune, de tentoonstelling in het Bijlokemuseum (1966), studies over de Sint-Lucasscholen, het oeuvre van architect en politicus Joris Helleputte, de archieven van het atelier BressersBlanchaert, Louis Cloquet, Arthur Verhaegen, Valentin Vaerwyck en Modeste de Noyette. 
2165. EVERAERT G., Blaffende honden worden verzilverd!, in @ rchieflink, 2, (2002), nr. 2, p. 1-2. Over de polychrome afwerking van de sculpturale versiering aan de Berg van Barmhartigheid in de Abrahamstraat, waaronder het wapenschild van bisschop Antoon Triest, Geïllustreerd.

2166. EVERAERT G., Meesterlijke sloten à l'Englesse van het hotel d'Hane Steenhuyse in Gent, in Monumenten en Landschappen, 20, (2001), nr. 5, p. 618. Bij de restauratie van dit adellijke stadspaleis bleven alle sloten bewaard en werden ze grondig bestudeerd. Zo kon de auteur, parallel aan de bouwgeschiedenis, een hele typologie opstellen en gegevens ontwarren inzake materiaalgebruik, technologie, soorten sloten. Ook werden inlichtingen over de vervaardigers ingewonnen, in het bijzonder over de 18de-eeuwse slotenmakers Pierre Guersouille en Jo De Blauwe. De bijdrage sluit af met enige duiding over de restauratie van deze sloten. Geillustreerd.

2167. GRIETEN S., Vreemd gebouwd. Westerse en niet-Westerse elementen in onze architectuur, s.1., 2002, 518 blz. Vijf eeuwen Zuid-Nederlandse bouwgeschiedenis die een aantal aspecten van beïnvloeding, navolging, overname en interactie in de architectuurgeschiedenis belichten. Vooral casestudy's gekozen in de provincie Antwerpen, maar toch veel verwijzingen naar Gentse architectuur. Uitgebreid kritisch apparaat. Geîllustreerd.

2168. KLUYSKENS P., Hoe de Achtersikkel gered werd, in Ghendtsche Tydinghen, 31, (2002), nr. 3, p. 122-127.

2169. KLUYSKENS P., Het "paleis" van de universiteit, in Ghendtsche Tydinghen, 30, (2001), nr.5, p. 290-298. Over de bouw van de Aula van de Universiteit in de Voldersstraat.

2170. LALEMAN M.C., Het prinselijk hof Ten Walle in Gent: recent onderzoek en nieuwe inzichten in Handelingen der Maatschappij voor Geschiedenis en Oudheidkunde te Gent, (2001), nr. LV, p.199-236. De bijdrage vormt één van de resultaten van het projectonderzoek dat in 1998 van start ging en enerzijds bedoeld was als een soort inventaris van de beschikbare kennis en anderszijds zou deze nieuwe kennis de basis vormen van een meervoudig beschermingsvoorstel. De auteur legt de klemtoon op de plaats van de site in de ontwikkeling van Gent, de betekenis van de site in ruimere context en de problemen rond een degelijk erfgoedbeheer van dit Gentse deelgebied. Geillustreerd.

2171. LAPORTE D. en F. HORSTEN, Begijnhoven in Vlaanderen, (Openbaar kunstbezit in Vlaanderen, 39), (2001), nr. 4, 43 blz. Themanummer gewijd aan de Vlaamse begijnhoven, waarin achtereenvolgens aandacht besteed wordt aan het ontstaan en de evolutie van de begijnenbeweging, aan de verschillende manieren waarop de begijnhoven tot ons gekomen zijn, aan 
het overzicht van de begijnhoven in Vlaanderen en tenslotte aan de erkenning van de Unesco. Alfabetisch op stadsnaam geklasseerd. De Gentse begijnhoven worden eveneens behandeld. Geillustreerd.

2172. LIEVOIS D., Erf, huis en mens. Huizenonderzoek in Gent, in Mores, 2 (2001), nr. 4, p. 9-10. Met verwijzing naar de nieuwe gelijknamige uitgave als handleiding voor huizenonderzoek in Gent. Geillustreerd.

2173. Onderzoek en restauratie van het monumentaal en archeologisch patrimonium, in Monumentenzorg en cultuurpatrimonium. Jaarverslag van de provincie Oost-Vlaanderen 2000, Gent, 2001, p. 91-228. Met bondige kroniekbeschrijvingen van werken uitgevoerd in het Belfort (Emile Braunplein), Spinnerij de Hemptinne (Opgeëistenlaan), het Stadhuis (Botermarkt), de SintJacobskerk (Bij Sint-Jacobs), de Sint-Jan-Baptistkerk in Afsnee, de SintSimon- en Sint-Judaskerk in Gentbrugge, de Centrale voor Huisvesting (Ravensteinstraat 12), de Sint-Baafskathedraal (Sint-Baafsplein) en de SintNiklaaskerk (Korenmarkt). Als auteurs van deze kronieken tekenden vooral P. DEVOS en L. ROBIJNS. Geillustreerd.

2174. PAS P., De waterwijk van Gent. Een wandeling in de buurt van het MIAT, in Tijdschrift voor Industriële Cultuur, 19, (2001), nr. 4, p. 2-23. De wandeling gaat langsheen Bij Sint-Jacobs, de Vrijdagmarkt, de Baudelostraat, de Wolfstraat, het Beverhoutplein, de Sint-Amelbergastraat, het Edward Anseeleplein, de Speldenstraat, de Waaistraat, het Raffinaderijstraatje, de Krommewal, de Gelukstraat, de Sint-Katelijnestraat, de Goudstraat, de De Beersteeg, de Minnemeersbrug, de Van Caeneghemstraat, de Blekersdijk, de Sint-Jorisbrug, de Ham, de Steendam, de Sint-Jansdreef, de Ijkmeesterstraat, de Bibliotheek en de Oudevest. Geillustreerd.

2175. POULAIN N. (red.), "IJzeren hek, sterk in blauwen steen gevestigd". Een wandeling langs fraai hekwerk ter aflijning van de Prinses Clementinalaan en de straten van het Miljoenenkwartier, Gent, 2001, 36 blz. Uitgave van de Dienst Monumentenzorg bij de dertiende Open Monumentendag rond het thema metaal. Geillustreerd.

2176. RABAU G., Begginagium S. Auberti Dictum Poort-Acker Fundatum An.1278, in GOV-Heraut, 36, (2001), nr. 4, p. 3-12. Overzicht van de geschiedenis van het Sint-Aubertusbegijnhof (Oude Houtlei).

2177. RAMBAUT A, Een ontdekkingstocht langs Gents gebrandschilderd glas, (Gentse Vereniging voor Stadsarcheologie), Gent, 2001, 28 blz. Een thematocht rond gebrandschilderd glas, georganiseerd op 20 oktober 2001, vormde de aanleiding voor toelichtingen over de glasschilderkunst in de $19 \mathrm{de}$ en de eerste helft van de 20ste eeuw, met bespreking van voorbeelden in de Sint-Baafskathedraal (Sint-Baafsplein), de Sint-Jozefkerk (Wondelgem- 
straat), de Onze-Lieve-Vrouw-Geboortekerk (Mariakerkeplein), de voormalige abdij (Drongen, Drongenplein) en de Sint-Martinuskerk (Eind Were). Er worden ook oudere glasfragmenten besproken, onder meer uit de SintBaafskathedraal en het Bijlokemuseum. Geillustreerd.

2178. RENOUX A, "Aux marches du palais": des mots, de concepts et des réalités fonctionelles et structurelles, in RENOUX, A (dir.), "Aux marches du palais"; Qu'est-ce un palais médiéval, Le Mans, 2001, p. 9-20. Introductie tot de bundel bijdragen van het VIIde Congres voor Middeleeuwse Archeologie dat van 9 tot 11 september 1999 in Le Mans plaatsvond en gewijd was aan het thema van de middeleeuwse paleizen in de ruime betekenis van de term. In de introductie wordt verder ingegaan op de terminologie en de betekenis van diverse termen die door archeologen, historici en kunsthistorici worden benut, al dan niet ondersteund door vermeldingen in eigentijdse geschreven bronnen. De auteur betreurt dat diverse aspecten onvoldoende zijn uitgediept zoals de invloed van de paleisarchitectuur (burchten, vorstelijke en adellijke residenties) op de burgerlijke architectuur. Bij de uitzonderingen op die algemene regel wordt er verwezen naar de middeleeuwse huizen in Gent.

2179. SLOCK W. \& W. HULSTAERT, Als de nood het hoogst is...20 jaar vakgebied architectuur, in Monumenten \& Landschappen, 21 (2001), nr. 1, p. 4654. Bijdrage over taken en realisaties van het vakgebied Architectuur van de Administratie Monumenten en Landschappen van het Vlaamse gewest, met verwijzing naar dringende instandhoudingswerken in de Gentse Sint-Stefanuskerk (1981) en een themastand op de beurs Flanders Technology International in de Flanders Expohallen van Sint-Denijs-Westrem $(1987,1989,1991)$.

2180. VAN DEN BOSSCHE H., 'Historische tuinen en parken' - meer dan groen op maat, in Monumenten \& Landschappen, 21, (2002), nr. 1, p. 4-19. Enkele voorbeelden van gerestaureerde en onderhouden historische tuinen waartoe de Administratie Monumenten en Landschappen van het Vlaamse Gewest heeft bijgedragen. Tot de besproken voorbeelden hoort de Hortus Michel Thiery aan het Berouw. In de jaren '30 legde schoolmeester Michel Thiery een voorbeeld van een plantentuin aan. $\mathrm{Na}$ enige tijd van verwaarlozing werd de tuin in zijn Thieryconcept geherwaardeerd en in een beschermd stadsgezicht opgenomen. Geillustreerd.

2181. VANDER STRAETEN M., Geschiedenis van de Hogeweg, in Jaarboek De Oost-Oudburg, (2001), nr. 38, p. 25-38.

2182. VAN DOORNE G., L'hôtel d'Hane à Gand: une "résidence royale, in Septentrion, 31, (2002), nr. 1, p. 74-76. Over de aanwezigheid van Lodewijk XVIII in het Hotel d'Hane Steenhuyse aan de Veldstraat in Gent tijdens de 100 dagen. Eveneens een bespreking van enkele bouwkundige elementen van dit pand met vorstelijke allures. 
2183. VAN DOORNE G. (dir.), Open Monumentendag 9 september 2001, (Stad Gent, Dienst Monumentenzorg), Gent, 2001, 44 blz. Diverse auteurs belichten een gebouw en vooral de bijdrage in dat gebouw rond het thema monumentaal metaal, het motto van de Open Monumentendag Vlaanderen 2001. Met een beknopte toelichting over: de Leopoldskazerne (Gaspard de Craeyerstraat), de N.M.B.S.-Werkplaatsen (Brusselsesteenweg, Gentbrugge), het cultuurcentrum De Centrale (Kraankindersstraat), de Sint-Annakerk (SintAnnaplein), de Arena Van Vletingen (Lange Violettenstraat), de Buurtloods (Patrijsstraat), het Museum voor Industriële Archeologie en Textiel (Minnemeers), de voormalige fabriek Carels (Dok Noord, Sassevaart, SintSalvatorsstraat), voormalige katoenloodsen (Voorhavenlaan), het laboratorium Soete van de Universiteit Gent (Sint-Pietersnieuwstraat), de voormalige katoenspinnerij de Hemptinne (Kolverniersgang, Opgeëistenlaan), een vroegere loods van de stukwerkers (New Yorkstraat), een practicumzaal van het Instituut voor Wetenschappen van de Universiteit Gent (Jozef Plateaustraat), de plantentuin van de Universiteit Gent (Karel Lodewijk Ledeganckstraat), het hotel d'Hane Steenhuyse (Veldstraat), de villa De Bondt (Krijgslaan), het De La Sallecollege (Oude Houtlei), de Heilig-Kruiskerk (Sint-KruisWinkeldorp, Sint-Kruis-Winkel), de Nemrodzaal (Goudstraat), de wintertuin van Hartmann (Henri Van Cleemputteplein, Sint-Amandsberg), het laboratorium Metallurgie van de Universiteit Gent (Technologiepark, Zwijnaarde), het atelier van Walter Duportail (Zwartekobenstraat, Zwijnaarde), een molen (Heerweg Noord, Zwijnaarde), de Sint-Eligiuskerk (Sint-Eligiusstraat, Gentbrugge), een stedelijke begraafplaats (Hundelgemsesteenweg, Ledeberg), de Onze-Lieve-Vrouw Sint-Pieterskerk (Sint-Pietersplein), het voormalige Poortakkerklooster (Oude Houtlei), het Kunstencentrum Vooruit (SintPietersnieuwstraat), een voormalige opslagplaats bekend als De Fabriek (Raffinaderijstraat), het Augustijnenklooster (Academiestraat), een kiosk (Dorpstraat, Zwijnaarde) en het Guislaininstituut (Jozef Guislainstraat). Geillustreerd.

2184. VINTS L., Kerk, katholieken en kunst. Documentatie, in Kadoc Nieuwsbrief, (2002), nr. 3, p. 19-20. Over kunstenaars-, architecten- en atelierarchieven in het Leuvense Katholiek Documentatie- en Onderzoekscentrum of KADOC. Met verwijzing naar onder meer het schilders- en beeldhouwersatelier Bressers-Blanckaert, de archieven van de Gentse glazeniers Joseph Casier en Gustave Ladon, en van beeldhouwer Aloös De Beule.

2185. WEYMEIS C., Het Land van Uilenspiegel. Damme, Knokke, Sluis, (Davidsfonds), Leuven, 2001, 130 blz. Met duiding van de haven op de Lieve in Damme en met toelichtingen over Vivenkapelle, neogotisch complex ontworpen door Jean Baptiste Bethune. Geillustreerd.

2186. Het wettelijk beschermd monumentaal patrimonium, in Monumentenzorg en Cultuurpatrimonium. Jaarverslag van de Provincie 
Oost-Vlaanderen 2000, Gent, 2001, p. 229-271. Met beknopte toelichtingen over de klinische en poliklinische instituten (Louis Pasteurlaan), een 19deeeuws herenhuis (Hoogstraat) en een hoeve (Drongen, Beekstraat).

\section{Kunst, cultuur}

2187. BOCCHERT T.H. (dir.), De eeuw van Van Eyck. De Vlaamse Primitieven en het Zuiden. 1430-1530, (Ludion), Gent, 2002, 280 blz. Uitgave naar aanleiding van een gelijknamige tentoonstelling in het kader van Brugge Culturele Hoofdstad 2002. De klemtoon in dit werk, waaraan diverse auteurs meewerkten, ligt op de relatie tussen de Vlaamse Primitieven en de schilders uit het zuiden van Europa. Het concept werd beïnvloed door twee vraagstellingen. Wat was de rol van dynastieke relaties in het Europa van de 15de eeuw voor de internationale verspreiding van de Vlaamse ars nova? Hoe en op welke manier hebben schilders uit de Lage Landen hun vakgenoten in het Zuiden van Europa beïnvloed? Vanuit die vraagstelling komen ook andere onderwerpen aan bod zoals stijl, techniek, iconografie, atelierwerking, economische relaties, mecenaat, cultuurhistorische context, en zo meer. De publicatie gaat uit van het oeuvre van Jan van Eyck. Geîllustreerd.

2188. CASSIMAN K., Evarist De Buck herontdekt, Beervelde, 2001, 14 blz. Catalogus bij de tentoonstelling over Evarist De Buck, georganiseerd naar aanleiding van het 75-jarige bestaan van de VDK-spaarbank. De tentoonstelling wil voornamelijk de veelzijdigheid van de individualistische Latemse kunstenaar tonen. Geillustreerd.

2189. DAANE M. en D. LEYMAN (red.), Gent de dubbelzinnige, (Stedenreeks het oog in't zeil, nr. 7), Beeldrecht-Amstelveen, 2000, 288 blz. Bespiegelingen over Gent door verschillende auteurs die, zelf Gentenaar of bezoeker van de stad, vooral over de contrasten en de dualiteiten van deze koppige en ontembare Vlaamse stad gepubliceerd hebben. Geillustreerd.

2190. D'HOLLANDER J., Pieter Le Blan (1711-1765). Gents veelzijdig beiaardier, in Clocke Roeland, 6, (2002), nr. 3 p. 3-9.

2191. FRERE J.C., De Vlaamse primitieven, (Librero), 2002, 208 blz. Naslagwerk met een overzicht in woord en beeld van het werk van Vlaamse primitieven, onder meer Melchior Broederlam, Hubert en Jan Van Eyck, Justus van Gent, en anderen. Geîllustreerd.

2192. GRIJP L. P. (red.), Een muziekgeschiedenis der Nederlanden met cdrom, Amsterdam, 2001, 916 blz. Muziekgeschiedenis gepresenteerd in 126 artikelen die de talrijke facetten belichten van de Nederlandse en de Vlaamse muziek. Niet alleen klassieke muziek, ook volks- en amateurmuziek 
evenals populaire muziek komen aan de orde, steeds in hun sociale en culturele context. In verschillende artikels komt Gent aan bod zoals bijvoorbeeld in het artikel van B. BOUCKAERT over de koralenscholen en het artikel van L.P. GRIJP over het zingen van psalmen in Gent tijdens de reformatie. Geîllustreerd.

2193. HEYMANS F., Het goud van de Vlaamse Letteren. 170 jaar prijzen voor de Nederlandse literatuur in België (1830-2000), Gent, 2001, 398 blz. Repertorium van alle literaire prijzen die sedert 1830 in België werden toegekend voor Nederlandstalig literair werk. Een grote indeling in prijzen van overheden en overheidsinstellingen en particuliere prijzen wordt nog in verdere items opgesplitst. Een aantal bijlagen ontsluit de gegevens in dit repertorium. Dit werk is de Belgische tegenhanger van een gelijkaardig Nederlands initiatief.

2194. HUYS P., De notities van J.B. Lybaert en van Armand Pauwels over kunstschilder Charles Picqué, in Bijdragen tot de geschiedenis van Deinze en de Leiestreek, LXVII, (2000), p. 91-110). Weergave van een tekst van J.B. Lybaert uit een schriftje dat zich in de Universiteitsbiliotheek van Gent bevindt en waarin notities opgetekend staan over Gentse schilders uit het begin van de 19de eeuw.

2195. Inventaire archeologique - fiche $n^{\circ} 35$, in Ghendtsche Tydinghen, 30 , (2001), nr. 6, p. 366. Heruitgave van een fiche, opgesteld door Louis Maeterlinck, in de rubriek Schilderijen-Museum voor Schilderkunst, nr. 114 XVII de eeuw over een schilderij van Nicolaas de Liemaekere, De verheerlijking van de Maagd.

2196. Inventaire archeologique - fiche $\mathrm{n}^{\circ} 36$, in Ghendtsche Tydinghen, 31 , (2002), nr. 1, p. 18-19. Heruitgave van een fiche, opgesteld door Louis Maeterlinck, in de rubriek Schilderijen-Museum voor Sierkunst nr. 14 XVIIde eeuw over een schilderij van Gaspard de Craeyer, De bekroning van de Heilige Rosalie.

2197. Inventaire archeologique - fiche $n^{\circ} 47$, in Ghendtsche Tydinghen, 31, (2002), nr. 2, p. 65-66. Heruitgave van een fiche, opgesteld door Hermann Van Duyse, in de rubriek Borduurwerk-Oudheidkundig Museum, nr. 1117 - XVIe eeuw, over de wapenrok van een heraut.

2198. Inventaire archeologique - fiche $n^{\circ} 55$, in Ghendtsche Tydinghen, 31, (2002), nr. 5, p. 205-206. Heruitgave van een fiche, opgesteld door Alphonse Diegerick, in de rubriek "Boekbanden-Staatsarchief St-Pietersabdij, n' 660 XVI eeuw" over een registerband van de 16de eeuw. 
2199. Inventaire archeologique - fiche $n^{\circ} 56$, in Ghendtsche Tydinghen, 31 , (2002), nr. 5, p. 277-278. Heruitgave van een fiche, opgesteld door Louis Maeterlinck, in de rubriek Schilderijen-Museum voor Schilderkunst nr. 104 XVIIde eeuw (1668) over een schilderij van Gaspard de Craeyer.

2200. Inventaire archeologique - fiche $n^{\circ} 849$, in Ghendtsche Tydinghen, 30 , (2001), nr. 5, p. 289. Heruitgave van een fiche, opgesteld door Hermann Van Duysse, in de rubriek Beeldhouwwerken-Oudheidkundig Museum - 16de eeuw - 1539 over een ere-blazoen van de gilde der schoenlappers (oudeschoenmakers).

2201. LIEVOIS D., Gijselbrecht van Meerlo, een Gentse beeldsnijder in het laatste kwart van de 15de eeuw in Handelingen der Maatschappij voor Geschiedenis en Oudheidkunde te Gent, (2001), nr. LV, p.179-197. Bijdrage over de weinig bekende beeldsnijder Gijselbrecht van Meerlo waarvan het oeuvre grotendeels verloren ging tijdens de beeldenstormen. Aanleiding tot de bijdrage is een los blad met notities, bewaard in het Stadsarchief in Reeks 20 (confiscatierekeningen), en die meer licht werpen op de confiscatiemaatregel in de nalatenschap van de Gentse beeldsnijder.

2202. LUST J., Het verzamelen van kunst en de Tweede Wereldoorlog, in Museumkrant Museum voor Schone Kunsten, Gent, 13, (2002), nr. 2, s.p. Met verwijzing naar een aantal schilderijen die het Gentse Museum voor Schone Kunsten in 1951 verwierf.

2203. LUYCKX F., Jan De Cock Pandschade fig. 7, in Museumkant Museum voor Schone Kunsten, Gent, 13, (2002), nr. 2 extra-editie, s.p. Cahier naar aanleiding van de gelijknamige tentoonstelling van de hedendaagse kunstenaar Jan De Cock in het Museum voor Schone Kunsten en het Stedelijk Museum voor Actuele Kunst of SMAK. Geillustreerd.

2204. NEYT V., Een tong van lijntses. Geannoteerde leeseditie van de Brieven van Pierken (1931-1935). Richard Minne - Frits Van den Berghe, Gent, 2002, 552 blz. Uitgave van de Koninklijke Academie voor Nederlandse Taal- en Letterkunde van de 'Brieven van Pierken', die Richard Minne tussen 1931 en 1935 heeft gepubliceerd in het satirische weekblad KoeKoek en in Vooruit. Bijdrage in een project van de Vakgroep Nederlandse Literatuur van de Gentse Universiteit, dat erop gericht is het werk van Richard Minne te bestuderen tegen de achtergrond van het tijdsgebeuren waarin het tot stand is gekomen. Uitgebreid kritisch apparaat en geillustreerd.

2205. SCHMIDT P., Het Lam Gods Gent, (Ludion Gids), Gent, (2001), 70 blz. Duidingen bij het Lam Gods-retabel van de Gebroeders Van Eyck, bewaard in de Sint-Baafskathedraal. Een gedetailleerde beschrijving wordt voorafgegaan door inleidende hoofdstukken rondom de betekenis van 
Vlaanderen in de 15de eeuw, de Sint-Janskerk, de opdrachtgevers van het retabel, de schilders en de geschiedenis van het kunstwerk. Geillustreerd.

2206. STERCKX M., Het (onzichtbare) monument ter ere van Emile Claus (1925-1926) door Yvonne Serruys, in Ghendtsche Tydinghen, 31, (2002), nr. 4, p.186-205; nr. 5, p. 262-277. Over het leven en het werk van de beeldhouwster en over historiek, betekenis en receptie van het publieke monument van Emile Claus in het Citadelpark te Gent.

2207. TEN BOKUM A. M. (red.), Bourdon 1811-1967, (Sterckshof Studies) nr. 22, Antwerpen, 2002, 320 blz. Publicatie bij een tentoonstelling georganiseerd in het Zilvermuseum Sterckshof. Case-study van de Gentse familiebedrijf Bourdon, incarnatie van de neogotiek in België op het vlak van de edelsmeedkunst. Een verbinding tussen de 18de-eeuwse Gentse zilverateliers en de tanende naoorlogse situatie van de meeste Belgische zilverbedrijven. Geillustreerd.

2208. VAN BELLINGEN S. (red.), re-Touche. 250 jaar schilders van de Koninklijke Academie van de Hogeschool Gent, Brussel, 2001, 200 blz. Publicatie bij een gelijknamige tentoonstelling die enerzijds een overzicht biedt van 250 jaar geschiedenis van deze instelling en anderzijds zeven verschillende items uit de schilderkunst naar voren brengt: (zelf)portret, tonaliteit, decoratieve fantasieën, lijn, kleur, mimesis en purgatorium. Geillustreerd.

2209. VANDE CASTEELE L., Artistieke bedrijvigheid van vrouwen in het oude Gent, in Het Tijdschrift van Dexia Bank, 55, (2001), nr. 4, p. 79-114. Overzicht van de vrouwelijke kunstenaars in de Gentse regio die gedurende de late Middeleeuwen, de Renaissance en de Barok bedrijvig waren in verschillende kunstdisciplines.

2210. VANDEVOORDE H., Vlaamsche Oogst, een blij mysterie uit de vooroorlogse letteren, in $Z L, 1,(2001), \mathrm{nr} .0$, p. 32-41. Over een onbekende tekst van Karel van de Woestijne, teruggevonden in het archief van de familie Herkenrath, en die moest dienen als inleiding bij een bloemlezing van Adolf Herkenrath uit Van Nu en Straks. Uit de tekst blijkt hoe Van de Woestijne zijn hele leven lang trouw is gebleven aan zijn visie op Van Nu en Straks.

2211. VAN ELSLANDE R., Het laatste oordeel (Diest, Stedelijke Museum) van Lieven Van der Clyte, in Ghendtsche Tydinghen, 30, (2001), nr. 6, p. 367371.

2212. VAN REYBROUCK D., De Plaag. Het stille knagen van schrijvers, termieten en Zuid-Afrika, Amsterdam, 2001, 302 blz. Op zoek naar de gronden van het plagiaat van een Zuid-Afrikaanse schrijver Eugène Marais, waaraan Nobelprijswinnaar Maurice Maeterlinck zich zou hebben schuldig 
gemaakt, komt de auteur onder meer terecht bij het Museum Vander Haeghen in Gent.

2213. Verwantschap \& eigenheid. Belgische en Nederlandse Kunst, 18901945, in Museumkrant. Mueum voor Schone Kunsten Gent, 13, (2002), nr. 2, s.p. Beknopte toelichting over de gelijknamige tentoonstelling naar het concept van M. LAMBRECHTS. Met verwijzingen naar verschillende kunstenaars die een band hebben met Gent of in het Museum voor Schone Kunsten vertegenwoordigd zijn. Geillustreerd.

\section{Materiële cultuur}

2214. BEYAERT M., Een ongewone uitdaging. Archeologisch onderzoek van de Dulle Griet-bombarde te Gent, in Stadsarcheologie. Bodem en monument in Gent, 23, (1999), nr. 1 p. 42-78. Uitgebreide weergave van het archeologisch en materieel technisch onderzoek dat op de 15 de-eeuwse bombarde, de Dulle Griet, kon worden uitgevoerd in het kader van restauratie- en conserveringswerken in 1998 en 1999. Geillustreerd.

2215. CLAESSENS-PERE A.M. \& L. DE REU, Dozen om te niezen. Belgische en Franse snuifdozen en tabaksraspen uit de 18de eeuw, (Sterckshof Studies nr. 6), Antwerpen, 1996. Studie over tabaksdozen met inleidende hoofdstukken, onder meer over het gebruik van de tabaksdoos aan het hof van gouverneur-generaal Karel Alexander van Lotharingen. Het corpus van deze publicatie, een catalogus van bewaarde tabaksdozen uit de 18 de eeuw, is per stad (productiecentrum) gerangschikt. Gent is er vertegenwoordigd met stukken die vooral door de edelsmeden Norbertus Heylbrouck (vader en/of zoon) werden vervaardigd, wat uit de merktekens kan worden afgeleid. Andere namen die de Gentse productie vertegenwoordigen zijn Jean du Moulin, Bartholomeus Gyselinck, AI. Deraisnes en Pieter Jozef Dupret. De catalogus sluit af met een lijst van de bijgeslagen merken. Aan het eind van de publicatie is een index opgenomen van Franse en Belgische edelsmeden en miniaturisten waarvan bekend is dat ze aan de vervaardiging van 18de-eeuwse tabaksdozen hebben meegewerkt. Geillustreerd.

2216. DE CLERCQ W., K. DE GROOTE, J. MOENS \& S. MORTIER, Zomergem, in Monumentenzorg en Cultuurpatrimonium. Jaarverslag van de Provincie Oost-Vlaanderen 2000, Gent, 2001, p. 192-196. Over archeologische bevindingen aan de Bauwermaan, met onder meer sporen van 12de-eeuwse kleiwinning en pottenbakkersactiviteit, wat een nieuw gegeven is voor de kennis van de lokale en regionale keramiekproductie in de regio Gent-Brugge. Geillustreerd.

2217. DE CLERCQ W., K. DE GROOTE, J. MOENS \& S. MORTIER, Zomergem-Oostwinkel, in Monumentenzorg en Cultuurpatrimonium. 
Jaarverslag van de Provincie Oost-Vlaanderen 2000, Gent, 2001, p. 186-189. Over archeologisch onderzoek op de site van Oostwinkel-Diepenbeek in Zomergem. De site bevatte ook sporen van 13de-eeuwse pottenbakkersactiviteit. Belangrijk voor de kennis van de middeleeuwse pottenbakkersactiviteit in de regio tussen Brugge en Gent. Geillustreerd.

2218. ERVYNCK A. \& W. VAN NEER, Dierenresten uit een waterput op de Nieuwe Beestenmarkt. Een blik op de voedselvoorziening van een vroegmiddeleeuws Gent, in Stadsarcheologie. Bodem en monument in Gent, 23, (1999), nr. 1, p. 5-13. Uitwerking van een vondstenensemble dat in 1991 werd opgegraven. De resultaten van het botonderzoek worden voorts gesitueerd ten opzichte van de ontwikkeling van het middeleeuwse Gent, waarbij ook vragen aan bod komen over voedseleconomie en consumptiepatronen in de vroege Middeleeuwen. Geillustreerd.

\section{Heemkunde, volkskunde, genealogie (-)}

2219. ANTHEUNIS V., Jeugdherinneringen (1930-1937) aan de sociale stadswoningen in de Lourdesstraat, nu Sint-Bernadettestraat, in Ghendtsche Tydinghen, 31, (2002), nr. 5, p. 294-297.

2220. BOERJAN G., Marka in de vorige eeuw, in Jaarboek Heemkundige Kring Marka, (2002) p. 3-41. Bijdrage over de geschiedenis van de heemkundige kring van Mariakerke.

2221. BRAEKMAN W.L., De blaasboog, een oud, volks muziekinstrument te Gent, in Ghendtsche Tydinghen, 31, (2002), nr. 4, p. 219-221.

2222. BRAEKMAN W.L., De Gentse metselaarsstaking van 1898, in Ghendtsche Tydinghen, 30, (2001), nr. 5, p. 320-325.

2223. BRAEKMAN W.L., Gaaischieting op de Waldam te Gent in 1714, in Ghendtsche Tydinghen, 31, (2002), nr. 5, p. 290-293. De informatie over deze gebeurtenis is afkomstig uit een lied, geschreven door de Gentse rederijker Jacobus Heije.

2224. BRAEKMAN W.L., Gentenaar "bevaen met drancke", gaat vreemd te Mariakerke in 1513, in Jaarboek Heemkundige Kring Marka, (2002), p. 4951.

2225. BRAEKMAN W.L., Het galgenveld te Mariakerke, in Jaarboek Heemkundige Kring Marka, (2001), p. 61-76. Bronnenmateriaal en chronologische opsomming van de terechtstellingen zoals Juliaan Brackeleirs, oprichter van de Heemkundige Kring Marka en volkskundige, het heeft opgetekend. 
2226. BRAEKMAN W.L., Jan Huyghes afscheid van de Mammelokker, in Ghendtsche Tydinghen, 31, (2002), nr. 3, p. 172-175.

2227. BRAEKMAN W.L., Lied op de "Kirremesse van Vinderheyte" in Ghendtsche Tydinghen, 30, (2001), nr. 6, p. 372-373.

2228. CASSIMAN P., De "Zang Maetschappy van Baerle" in Dronghine, Jaarboek, 2002, p.101-110.

2229. CLAESSENS H., De families Compare - Fredericq - Loveling - Buysse in Vlaamse Stam, 38, (2002), nr. 1, p. 1-25. Genealogische gegevens met betrekking tot deze families.

2230. CLAEYS F., De watering Oude Kale en Meirebeek, in Dronghine, Jaarboek, 2002, p. 65-68. Over de wateringen van de vroegere gemeente Drongen, waaronder de watering Oude Kale en Meirebeek.

2231. COLLUMBIEN H., Gentse memoriedagen: 14 en 15 mei in Ghendtsche Tydinghen, 30, (2001), nr. 5, p. 320-325; 16 en 17 mei, nr. 6, p. 388-396; 18 en 19 mei, 31, (2002), nr. 1, p. 30-36; 20, 21 en 22 mei, nr. 2, p.97-103; 23 en 24 mei; nr. 3, p. 151-157; 25-26-27-28 mei, nr. 4, p. 245-256; 29-30-31 mei, nr. 5, p. 301-308.

2232. DE BAETS A., Merelbekenaars overleden in Gent, in Gentse Cadenas, XXI, (2002), nr. 2, p. 5-6.

2233. DE CRUZ H. \& J. DE SMEDT, De miniatuurkathedraal van Jan Baptist Minne in het Huis van Alijn, in Oost-Vlaamse Zanten, LXXVI, (2001), nr. 4, p. 374-389. Beschrijving van de miniatuurkerk die deel uitmaakt van de collectie van het huis van Alijn. Informatie was vooral afkomstig uit interviews met de schoondochter en de kleinzoon van deze volkskunstenaar en uit zijn handgeschreven memoires.

2234. DE SMET N., De Geschiedenis van het Gentbrugse zwembad "Palm Beach"in Land van Rode, 30, (2002), p. 2-12.

2235. DE SMUL R., Bioscopen te Gent en omliggende gemeenten, in De Draeke, 25, (2002), nr. 3, p. 9-14.

2236. DEVRIESE L., De abt van Baudelo liquideert de "Venusbergh" en andere zondige gelegenheden in Ghendtsche Tydinghen, 31, (2002), $\mathrm{nr} .2$, p. 66-72. Een voorbeeld van hoe religieuze gemeenschappen hun omgeving moreel en maatschappelijk onder druk konden zetten om de kloosterlijke rust te vrijwaren. 
2237. DE VUYST J., Het geheim leger vecht $\left(1^{\mathrm{e}}\right.$ deel), in Ghendtsche Tydinghen, 30, (2001), nr. 5, p. 266-288; tweede deel in Ghendtsche Tydinghen, 30, (2001), nr. 6, p. 347-365; derde en laatste deel in Ghendtsche Tydinghen, 31, (2002), nr. 1, p. 2-18. Aangevulde en verbeterde versie van Het Geheim Leger vecht (uitg. Fiat, Gent), in 1945 verschenen, en waarin J. De Vuyst de krijgsverrichtingen van zijn peloton in de schoot van Le Héron en de Groupe Mobile-La Sarcelle beschrijft.

2238. DUMONT W., De wereldtentoonstelling van Gent en hare geschiedenis - 1913, in Ghendtsche Tydinghen, 31, (2002), nr. 3, p. 148-150. Bijdrage over de wereldtentoonstelling zoals opgetekend door een tijdgenoot.

2239. FACK R., Het wel en wee van een brouwerij te Mariakerke, in Heemkundige Kring Marka, Jaarboek 2001, p.43-57. Bijdrage over brouwerij De Roos van de familie Saudan, naar aanleiding van de vondst van oude documenten bij opruimingswerken in het gebouw.

2240. FRANSSEN T. (ed.), Museumstukken in privebezit. Pronkstukken van particuliere Gentse verzamelaars, Gent, 2002, 68 blz. Catalogus bij een tentoonstelling georganiseerd door de Gentse verzamelaarsclub "De Draak", naar aanleiding van het 25-jarige bestaan van de club. De meest uiteenlopende voorwerpen komen aan bod zoals communiekapelletjes, missiebusjes, loterijbiljetten, Gents commercieel briefpapier, en zo meer. Geillustreerd.

2241. HUYS P., Molennieuws in de "Gazette van Gend (1826), in Molenecho's, 30, (2002), nr. 1, p. 50-53. Verwijzingen naar de verkoop van molens, onder andere uit Gent, Oostakker, Ledeberg en Wondelgem.

2242. HUYS P., Molensprokkelingen van anderhalve eeuw geleden, in Molenecho's, 30, (2002), nr. 2, p. 107-108. Verwijzingen naar de verkoop van de drie papiermolens uit Gent en van windmolen "De Koeye" uit de Holstraat.

2243. KLUYSKENS P., De buikspreker Alexandre, in Ghendtsche Tydinghen, 31, (2002), nr. 5, p. 290-293. Artikel dat vijftig jaar geleden geschreven werd door de auteur onder de titel Een klein schandaal te Gent in 1820. De universiteit schenkt een zilveren medaille aan een buikspreker.

2244. LABYN M., Gentse hotels vroeger en nu, in De Draeke, 25, (2002), nr. 3, p. 15-18.

2245. LEKENS L. \& J. DECAVELE, Het Campo Santo in 131 levensverhalen, (Gent Cultuurstad vzw), Gent, 2001, $159 \mathrm{blz}$. De publicatie biedt levensverhalen van personen die op de Kapelleberg in Sint-Amandsberg, in het Campo Santo, werden bijgezet. Het overzicht wordt voorafgegaan door een 
beknopte historische schets van de site. Met situering van de grafmonumenten in een overzichtelijke lijst en op plattegronden. Geíllustreerd.

2246. LEVIS E., 't Gentsch spant de kruune, in Ghendtsche Tydinghen, 31, (2002), nr. 1, p. 37-48.

2247. LEVIS E., 't Gentsch spant de kruune. Reinaert in Gent en in't Gentsch, in Ghendtsche Tydinghen, 31, (2002), nr. 4, p. 229-242.

2248. LIEVOIS D., Openbare zedenschennis bij het doopfeest van Karel van Habsburg, in Ghendtsche Tydinghen, 31, (2002), nr. 3, p. 134-135. Over Jehan Molinet, indiciaire ten dienste van de Bourgondische dynastie, die een boete opliep wegens het urineren tegen het Gravensteen.

2249. MANESSE M., Het gebeurde 50 jaar geleden, in Jaarboek Heemkundige Kring Marka, 2001, p. 81-100; 2002, p. 153-172.

2250. MANESSE M., Mariakerke anno 1804, in Jaarboek Heemkundige Kring Marka, 2002, p.101-172.

2251. OSSIEUR E., Hermafrodiet te kijk in 1669, in Ghendtsche Tydinghen, 30, (2001), nr. 5, p. 316-320.

2252. OSSIEUR E., Ondergedoken begrafenisregister van Sint-Veerle gelokaliseerd, in Gentse Cadenas, XXI, (2002), nr. 2, p.11.

2253. PEENE W., Het Roeselaarse verhaal Vanpeene in de zestiende eeuw (deel 2), in Vlaamse Stam, 38, (2002), nr. 7-8, p. 366-370. Mogelijke banden tussen de Roeselaarse familie Van Peene en de Gentse voorouders van Hypoliet Van Peene, de tekstdichter van het Vlaamse volkslied.

2254. SCHELSTRAETE L. \& A. DEWETTINCK, Wat d'Assels was...en nog een beetje is, in Dronghine, Jaarboek, 2002, p. 133-147. Jeugdherinneringen van de auteurs uit de jaren ' 40 en ' 50 over het dagelijkse leven in de Assels, een gebied dat op de grens ligt van de gemeenten Drongen en Afsnee.

2255. SERMON A., Carnaval, Gent, 2001, 295 blz. De auteur schetst de ontwikkeling van het carnavalsfeest van de Middeleeuwen tot heden, vooral de manier waarop door kerk en overheid werd gepoogd om het in te dijken. Ook een aantal maatschappelijke evoluties droegen bij tot het verdwijnen van de traditionele volkscultuur. De nadruk komt heel sterk te liggen op de situatie in Gent. Geîllustreerd. 
2256. S.N., Het honderdjarig bestaan van de koninklijke Oud-leerlingenOuders-en Vriendenbond van de Rijksmiddelbare School Gent (KOLMS) 1852-2002, Gent, 2002, 104 blz. Geillustreerd.

2257. STEEGHERS W., Gentse poorters uit Waregem (1542-1796), in Vlaamse Stam, 38, (2002), nr. 7-8, p. 412.

2258. STEEGHERS W., Overleden begijntjes van het Groot Begijnhof SintElisabeth te Gent, uit Vinderhoute, in Vlaamse Stam, 38, (2002), nr. 7-8, p. 411.

2259. Kant. Teksten van de studiedag rond kant te Gent (Gent, 20 oktober 2001), in Oost-Vlaamse Zanten, LXXVIII, (2002), nr. 1, p. 1-60. Aanleiding voor dit thema vormden de twee tentoonstellingen over kant in Brugge en in Lille. Eerst komt een artikel van M. BRUGGEMAN dat een overzicht biedt van de kant in Europa tussen de 16de en de 18de eeuw, met verwijzingen naar de Gentse kant. Verder zijn er ook de bijdragen van N. BRACKE over de kantwerkscholen tijdens de tweede helft van de 19de eeuw en van R. DE HERDT over de textilia in het bezit van het MIAT. Met verwijzingen naar Gentse situaties.

2260. VAN BOST F., De prentkaarten van uitgever Th. De Graeve-Gent, in De Draeke, 25, (2002), nr. 3, p. 3-8.

2261. VAN PETEGHEM J., Over interlokaal vervoer op de Moervaart en het kanaal Gent-Terneuzen, in Jaarboek De Oost-Oudburg, (2001), nr. 38, p. 159-168.

2262. VAN RYSSEL D., Ik zou daar een boek kunnen over schrijven. De charmes van de dagelijksheid (vervolg), in Ghendtsche Tydinghen, 30, (2001), nr. 5, p. 305-316; nr. 6, p. 374-386; 31, (2002), nr. 1, p. 20-29; nr. 2, p. 73-88; nr. 3 , p. $136-147$; nr. 4, p. 206-219.

2263. VERAVERBEKE E., In de schijnwerper: de fanfare van de kulders, in Oost-Vlaamse Zanten, LXXVI, (2001), nr. 4, p. 372-373. Korte toelichting over de fanfare van de kulders naar aanleiding van het verwerven door het Huis van Alijn van de instrumenten van deze fanfare.

2264. VERMEULEN N., Het heroïsche verhaal van de Messageries Steurbaut, in Interbellum, 22, (2002), nr. 2, p. 7-15. Geschiedenis van een transportbedrijf, opgericht kort na de Eerste Wereldoorlog en gelegen in de huidige Simon de Mirabellostraat. Het wel en wee van dit bedrijf dat ophield te bestaan in 1958 werd verteld door G. STEURBAUT en bewerkt door $\mathbf{N}$ VERMEULEN.

2265. WAERI P., Verzameling der volledige Kluchtige en Politieke liederen van Karel Waeri den Gentschen Beranger met bijvoeging van het portret en de 
beknopte levensbeschrijving van den Gentschen volksdichter, Gent, 2001, 494 blz. Heruitgave door de v.z.w. Geschiedkundige Heruitgeverij van deze publicatie uit 1899.

\section{Biografieën (-)}

2266. CALLANT E., Jan Van den Eeden, in Ghendtsche Tydinghen, 31, (2002), nr. 5, p. 311-319. Artikel verschenen in het Zondagsblad van 17 maart 1918, m.b.t. de Gentse toondichter Jan Van den Eeden.

2267. CREVE P. (red.), Getuigen. Armand Verspeeten, Gent, 1999, 88 blz. In de reeks Getuigen brengt het AMSAB autobiografische nota's van figuren die nauw vervlochten waren met de socialistische arbeidersbeweging, onder meer Armand Verspeeten. Geillustreerd.

2268. DAANE M., De vrijheid nog veroveren. Richard Minne 1891-1965, Antwerpen-Amsterdam, 2001, $552 \mathrm{blz}$. Documentair portret waarin relevante levensfeiten samengebracht zijn in combinatie met schetsen van Minnes tijd en omgeving. Het oeuvre van Richard Minne is immers nauw verbonden met zijn leven. Tevens aandacht voor zijn journalistieke werk.

2269. DE CLERCQ M., Pedro de Gante op Canvas. Een interview met Paul Ghijsels, in GOV Heraut, 37, (2002), nr. 3, p. 6-9. Gesprek met P. Ghysels over de franciscaanse missionaris Pedro de Gante, naar aanleiding van een documentaire op Canvas.

2270. DECAVELE J. (red.), Robert van Pottelbergh herdacht, in Jaarboek De Oost-Oudburg, (2001), nr. 38, p. 199-205.

2271. DEVOLDER K., Frans De Poter - leven en werk, in MEERSSEMAN S., Gent van den oudsten tijd tot heden. Registers op het werk van Frans De Potter, (Verhandelingen der Maatschappij. voor Geschiedenis en Oudheidkunde te Gent, 27, Gent, 2002, p. 7-14. Beknopte levensschets over Frans De Potter (1834-1904), als inleiding op de publicatie van een register op zijn achtdelige werk Gent van den oudsten tijd tot heden.

2272. DORIKENS M., Joseph Plateau. Leven tussen kunst en wetenschap, (Provincie Oost-Vlaanderen), Gent, 2001. Overzichtelijke mensschets van de in Brussel geboren Joseph Plateau (1801-1883) die vooral bekend staat om zijn experimenten in de fysica aan het Instituut voor Wetenschappen en het grootste deel van zijn leven in Gent doorbracht. Een aantal van zijn vindingen, zoals de anorthoscoop van 1829 en de fenakistiscoop van 1832, hebben bijgedragen tot de verdere ontwikkeling van de filmindustrie. Geillustreerd. 
2273. GOETHALS J., De voorouders van generaal George Washington Goethals. Bouwmeester van het Panamakanaal, in Vlaamse Stam, 37, (2001), nr. 10, p. 477-495. Genealogie van de familie Goethals met onder andere een tak uit Gent.

2274. IMBO G., Daniël Heins. Latinist, hellenist, dichter, filosoof, theoloog, historiograaf, "ster van Leiden", Hollands Calvinist (contra-remonstrant) met Geraardbergse "roots" (deel I) in De Heemschutter, 185, (2002), nr. 5, p. 24-30. Geboren te Gent in 1580 moest Daniël Heins tijdens de zomer van 1583 met zijn ouders vluchten naar Vere en later naar Engeland omwille van de inname van de stad door de troepen van Farnese (in 1584). Bijdrage over zijn studies, zijn jeugdwerk, zijn cursus aan de Leidse universiteit en andere momenten uit zijn loopbaan.

2275. KLUYSKENS P., Jos Clemmen, in Ghendtsche Tydinghen, 31, (2002), nr. 2, p. 58-65. Heruitgave van een artikel verschenen n.a.v. de 200ste verjaardag van het overlijden van de eerste katoenbaron Jos Clemmen.

2276. KWANTEN G., August-Edmond De Schrijver 1898-1991. Politieke biografie van een gentleman-staatsman, (Kadoc-Studies, 27), Leuven, 2001, 688 blz. Uitgebreid kritisch apparaat. Politieke biografie die de visie, de drijfveren, de politieke strategie en de stijl analyseert van de Belgische politicus AugustEdmond De Schrijver (1898-1991). Meteen krijgt de lezer een overzicht van de Belgische politiek tussen 1928 en 1965, met als enkele grote aandachtspunten, de Vlaamse emancipatiebeweging, het beleid van het oorlogskabinet, de Koningskwestie, de Schoolkwestie, de decolonisatie, en zo meer. Geillustreerd.

2277. LEKENS L., Bouwmeester Louis Minard 1801-1875, in GOV Heraut, 37, (2002), nr. 3, p. 3-6.

2278. LOUWERSE J., Een vreemde tante, in @ rchieflink, 2 (2002), nr. 3, p. 6-7. Beknopt levensverhaal over Johanna Paulina Musters (1878-1895), een kleine vrouw van $59 \mathrm{~cm}$ groot die als prinses Paulina over de hele wereld werd opgevoerd in kermis- en theaterattracties. Heel wat foto's en spullen, bewaard in museum Den Aanwas in het Nederlandse Ossendrecht, zijn afkomstig uit Gent. Maar ook het Stadsarchief bewaart documenten over dit bijzondere personage. Emile Grandsart, een Gentse kermisexploitant, was zeker én van haar managers. Geillustreerd.

2279. MUSSCHOOT D., Halfweg...het leven van Koen Crucke, Tielt, 2001, $224 \mathrm{blz}$. Dit boek dat het leven vertelt van de populaire Vlaamse operazanger en radio- en televisiester Koen Crucke, is het resultaat van dagenlange gesprekken met journalist Dirk Musschoot. Tal van anekdotes uit zijn jeugdjaren in Gent, uit zijn carrière aan de Gentse Opera, bij radio en televisie, en zo meer. Geillustreerd. 
2280. POELMAN R., Jef Crick, zijn loopbaan en zijn oude dag, in Jaarboek De Oost-Oudburg, (2001), nr. 38, p. 63-88. Bijdrage over schrijver, journalist, kunstkenner en heemkundige Jef Crick, gebaseerd op een dossier uit het Documentatiecentrum voor Streekgeschiedenis en op enkele documenten uit het persoonlijk archief van de auteur.

2281. SCHEPENS E., Familie Eich, bouwers van straatorgels, pianola's, radio's, pick-ups en jukeboxen, in Jaarboek De Oost-Oudburg, (2001), nr. 38, p. 169-198.

2282. VAN DAELE J., Van Gent tot Genève. Louis Varlez. Een biografie. Gent, 2002, 250 blz. Aan de hand van het rijk gevulde levensverhaal van Louis Varlez, de gedreven exponent van een late 19de-eeuwse radicaal-liberale familie wordt een stuk sociale geschiedenis van Gent geschreven: jeugdjaren en studies, de maatschappelijke situatie in Gent en het Gentse stelsel van de werkloosheidsverzekering met name het Gentse model, zijn carrière als hoogleraar en zijn internationale carrière in Londen en Genève zijn de belangrijkste pijlers van deze studie. Geillustreerd.

2283. VERDUYN G., Kanunnik Désiré Verduyn (Izegem 1792-Gent 1869), in Ten Mandere, 41, (2001), nr. 3, p. 3-28. Schets van de carriere van Désiré Verduyn tegen de achtergrond van de 19de-eeuwse troebelen, onder andere tussen Napoleon en bisschop de Broglie, tussen Willem I en de anti-orangistische geestelijkheid en tussen de Ultramontanen en de liberaal-katholieken. Geillustreerd.

2284. VERHEEKE G. (red.), Frans Balthazar. (onvoltooide) Memoires van een letterzetter, Gent, 2001. 576 blz. Egodocument van de letterzetter Frans Balthazar, geboren in 1914, dat een boeiend zicht biedt op een stukje sociale geschiedenis van Gent. Herinneringen aan familie, jeugdjaren, het Gent van toen, het werk in de drukkerij, het dagelijkse leven, en zo meer. Geillustreerd. 


\section{Index}

\begin{tabular}{|c|c|c|c|}
\hline ANTHEUNIS V. & 2219 & \multicolumn{2}{|c|}{ DESEIJN G. $2101,2114,2131,2132,2133$} \\
\hline BACKS J. & 2109 & DE SMEDT J. & 2233 \\
\hline BAECK M. & 2128 & DE SMET N. & 2234 \\
\hline BAILLIEUL $\mathbf{B}$. & 2144 & DE SMET S. & 2102 \\
\hline BARBRY R. & 2094 & DE SMUL $R$. & 2235 \\
\hline BAUTERS L. & 2081 & DE STAELE $H$. & 2057 \\
\hline BEYAERT M. & 2214 & DEVOLDER $\mathbf{K}$. & 2271 \\
\hline BLAISING J.M. & 2067 & DEVOS G. & 2081 \\
\hline BOCCHERT T.H. & 2187 & DEVOS P. & $2157,2158,2159$ \\
\hline BOERJAN G. & 2145 & DEVREKER J. & 2081 \\
\hline BOERJAN G. & 2220 & DEVRIESE L. & $2134,2160,2161,2236$ \\
\hline BOONE M. & 2082 & DEVRIEZE A. & 2115 \\
\hline BOURGEOIS J. & 2053 & DE VUYST J. & 2237 \\
\hline BRAECKMAN W.L. & $2095,2221-2227$ & DE VUYST W. & 2058,2162 \\
\hline BROES K. & 2146 & DE WAELE M. & 2116,2117 \\
\hline BUSSELS S. & 2096,2097 & DEWETTINCK A. & 2254 \\
\hline CALLANT E. & 2266 & DE WILDE J.R.J. & 2103 \\
\hline CALLEBAUT $\mathrm{N}$. & 2147 & DHAENE S. & 2074 \\
\hline CARLIER M. & 2083 & D'HOLLANDER J. & 2163,2190 \\
\hline CASSIMAN K. & 2188 & DIERKENS A. & 2164 \\
\hline CASSIMAN P. & $2098,2110,2228$ & DILLEN K. & 2118 \\
\hline CAUCHIES J.M. & 2054 & DORIKENS M. & 2272 \\
\hline CELIS M. & 2148 & DOUXCHAMPS $\mathrm{J}$. & 2059 \\
\hline CHARLES L. & 2055, 2073, 2084 & DUMONT W. & 2238 \\
\hline CLAESSENS H. & 2229 & ERVYNCK A. & 2218 \\
\hline CLAESSENS-PERE A.M. & 2215 & EVERAERT G. & $2162,2165,2166$ \\
\hline CLAEYS F. & 2230 & EVRARD K.A. & 2075 \\
\hline COENE A. & $2149,2150,2151$ & FACK R. & 2239 \\
\hline COHEN H. & 2152 & FALTER R. & 2093 \\
\hline COLLUMBIEN H. & 2231 & FRANSSEN T. & 2240 \\
\hline CONVENTS G. & 2111 & FRERE J.C. & 2191 \\
\hline CREVE P. & 2267 & GOETHALS J. & 2273 \\
\hline DAANE M. & 2189,2268 & GRIETEN S. & 2167 \\
\hline DAMBRUYNE J. & 2099 & GRIJP L.P. & 2192 \\
\hline DE BAETS A. & 2232 & GUZZETTI L. & 2085 \\
\hline DE BLEECKER M. & 2056 & HEIRMAN M. & 2119 \\
\hline DECAVELE J. & 2245,2270 & HERMAN S. & 2120 \\
\hline DECEULAER H. & 2100 & HEYMANS F. & 2193 \\
\hline DECLERCQ G. & 2139 & HEYRMAN P. & 2060,2124 \\
\hline DE CLERCQ M. & 2269 & HORSTEN F. & 2171 \\
\hline DE CLERCQ W. & 2216,2217 & HULSTAERT W. & 2179 \\
\hline DE CLOET F. & 2112 & HUYS P. & $2194,2241,2242$ \\
\hline DE CRUZ H. & 2233 & IMBO G. & 2274 \\
\hline DE GROOTE K. & 2216,2217 & JANSSENS U. & 2076 \\
\hline DE HERDT R. & 2129 & KLUYSKENS P. & $2168,2169,2243,2275$ \\
\hline DE KEYZER L. & 2153 & KWANTEN G. & 2276 \\
\hline DELCART A. & 2130 & LABYN M. & 2244 \\
\hline DE NEEF G. & 2057 & LALEMAN M.C. & $2055,2068,2069,2070$ \\
\hline DENEWET L. & 2154,2155 & 2170 & \\
\hline DE PLUS J. & 2128 & LAPORTE D. & 2171 \\
\hline DE REU L. & 2215 & LARSEN N.-E. & 2087 \\
\hline DERUELLE M.I.J. & 2156 & LEDERER D. & 2104 \\
\hline DERWAEL J. & 2113 & LEKENS L. & 2245,2277 \\
\hline
\end{tabular}




\section{INDEX}

LENDERS P.

LEVIS E.

LEYMAN D.

LIEVOIS D.

LOUWERSE J.

LUST J.

LUYCKX F.

LYON B.

LYON M.

MAES D.

MANESSE M.

MATTHYS A.

MAZEURE N.

MEERSSEMAN S.

MEGANCK $M$.

MEILLANDER V.

MIHAIL B.

MOENS J.

MOREAU R.

MORTIER S.

MUSSCHOOT D.

NEYT V.

OOSTERBOSCH M.

OSSIEUR E.

PAS P.

PEENE W.

POELMAN R.

POULAIN N.

RABAU G.

RAMBAUT A.

RENOUX A.

SAERENS L.

SCHELSTRAETE L.

SCHEPENS E.

SCHMIDT $P$.

SEGHERS Y.

SEMEY J.

SERMON A.

SLOCK W.

STEEGHERS W.

STERCKX M.

STOOPS G.

TAYMANS $H$.

TEN BOKUM A.M.

THIELEMANS S.
2105

2246, 2247

2189

$2172,2201,2248$

2278

2202

2203

2088

2088

$2089,2121,2140$

$2135,2249,2250$

2071

2141

2061

2053

2055

2164

2216, 2217

2134

2216, 2217

2122, 2279

2204

2062

2251, 2252

2142, 2174

2253

2063, 2064, 2280

2175

2176

2069, 2177

2178

2065

2254

2106, 2281

2205

2057

2053

2255

2179

2257, 2258

2206

2069, 2070

2136

2207

2077
TONDAT R.

VAN ACKER K.G.

VAN BELLINGEN S.

VAN BOST F.

VAN CAENEGEM R.

VAN DAELE $J$.

VANDAMME L.

VANDE CASTEELE $L$.

VAN DEN BOSSCHE $\mathrm{H}$.

VANDERHAEGEN G.

VAN DER HERTEN $B$.

VANDERPUTTEN S.

VANDER STRAETEN $M$.

VANDEVOORDE $\mathrm{H}$.

VANDEWALLE G.

VAN DOORNE G.

VAN ELSLANDE R.

VAN GANSBEKE J.

VAN HAMME $H$.

VANHAUTE E.

VAN HEESVELDE $P$.

VAN MEERTEN $M$.

VAN MOLLE L.

VAN NEER W.

VAN OOSTVELDT B.

VAN PETEGHEM J.

VAN REYBROUCK D.

VAN RYSSEL D.

VERAVERBEKE E.

VERBEKE A.

VERBEURGT G.

VERBOVEN $\mathrm{K}$.

VERBRUGGEN J.F.

VERDUYN G.

VERHEEKE G.

VERMEIR R.

VERMEIREN G.

VERMEULEN A.

VERMEULEN N.

VIAENE $P$.

VINTS L.

WAERI P.

WEYMEIS C.

WUYTS E.
2107

2090

2208

2260

2091

2282

2078

2209

2180

2074

2079

2143

2181

2210

2080

2182,2183

2211

2137

2092

2115

2123

2079

2124

2218

2097

2261

2212

2125, 2262

2074, 2263

2056

2079

2066

2093

2283

2284

2108

2069, 2070

2126

2264

2138

2184

2265

2185

2127 